\title{
The Influence of Aggregate Size and Binder Material on the Properties of Pervious Concrete
}

\author{
Tun Chi Fu, Weichung Yeih, Jiang Jhy Chang, and Ran Huang \\ Department of Harbor and River Engineering, National Taiwan Ocean University, 2 Pei-Ning Road, Keelung 20201, Taiwan \\ Correspondence should be addressed to Weichung Yeih; wcyeih@mail.ntou.edu.tw
}

Received 21 August 2014; Revised 26 September 2014; Accepted 26 September 2014; Published 21 October 2014

Academic Editor: Aiguo Xu

Copyright (C) 2014 Tun Chi Fu et al. This is an open access article distributed under the Creative Commons Attribution License, which permits unrestricted use, distribution, and reproduction in any medium, provided the original work is properly cited.

\begin{abstract}
Specimens were prepared by altering parameters such as aggregate sizes, binder materials, and the amounts of binder used and were subsequently tested by using permeability, porosity, mechanical strength, and soundness tests. The results indicated that the water permeability coefficient and connected porosity decreased as the amount of binder used increased and increased with increasing aggregate size. In the mechanical strength test, the compressive, splitting tensile, and flexural strengths increased as the amount of binder used increased and decreased with the increase of aggregate size. Highly viscous binder enhanced compressive strength, water permeability, and the resistance to sulfate attacks. In the mechanics and sulfate soundness tests, the mix proportion of alkaliactivated slag paste used in this study exhibited a superior performance than the Portland cement pervious concrete (the control) did, but the difference in water permeability between the two types of concrete was insignificant. The mix proportions of cement paste containing $20 \%$ and $30 \%$ silica fume exhibited less mechanical strength than the control did. Moreover, compared with the control, the cement paste containing silica fume demonstrated poor resistance to sulfate attacks, and the difference in the water permeability between such specimen and the control was not noticeable.
\end{abstract}

\section{Introduction}

Pervious concrete, also known as no-fines concrete, is a type of porous composite material that can be regarded as concrete composed of minimal to fine uniformly graded aggregates and a limited amount of cement paste. Because of its pervious properties, the pervious concrete pavement provides a better temperature and humidity exchange between atmosphere and earth than the impervious pavement such that the socalled "heat-island" effect in the urban region can be reduced. In addition, pervious concrete is regarded as a remedy for the flood control due to its excellent water permeability. Also, it is known that the pervious concrete pavement reduces traffic noise and has an excellent antiskid performance.

However, a lower mechanical strength of pervious concrete constrains the application of pervious concrete. Due to the porosity inside the pervious concrete, its compressive strength does not satisfy the minimal requirement for the structural concrete (21 MPa for 28-day compressive strength). Therefore, most applications for pervious concrete are parking lot pavement, pedestrian walkway, bike route, and places where concrete compressive strength is not important. In the following, literature survey for pervious concrete is given.

Generally, because of the high amount of connected voids in pervious concrete, compressive strength is relatively low; thus, the strength of pervious concrete can be improved using the following strategies [1]:

(1) enhancing the characteristics of binder by decreasing the water-cement $(\mathrm{w} / \mathrm{c})$ ratio and adding pozzolanic materials such as silica fume;

(2) adopting different binder materials such as using epoxy to replace cement pastes;

(3) applying slight pressure and increasing the temperature in the curing stage.

Marolf et al. studied the effect of aggregate size and gradation on the acoustic absorption for pervious concrete. They reported that pervious concrete mixtures with singlesized aggregates provide substantial improvement to sound absorption as compared with conventional concrete [2]. Park et al. studied the sound absorption properties of pervious 
concrete using recycled aggregate and various target void ratios. They reported that the sound absorption characteristics of the porous concrete using recycled waste concrete aggregate showed that the Noise Reduction Coefficient (NRC) was optimum at the void ratio of $25 \%$ but the percent content of the recycled aggregate had very little influence on the NRC. Therefore, they concluded that the optimum void ratio is $25 \%$ and the recycled aggregate is $50 \%$ [3].

Park and Tia studied water purification effect of pervious concrete. They found that a porous concrete with a smaller size of aggregate and a higher void content was found to have superior ability of the removal of the total phosphorus and total nitrogen in the test water. They concluded that this effect is due to the large specific surface area of the porous concrete [4]. Huang et al. reported the properties of polymer-modified pervious concrete and they concluded that it was possible to produce pervious concrete mixture with acceptable permeability and strength through the combination of latex and sand [5]. Crouch et al. studied the aggregate effect on the static elastic moduli of pervious concrete and they reported that an increased aggregate amount resulted in a statistically significant decrease in both compressive strength and static elastic moduli due to the subsequent decrease in paste amount [6]. Chindaprasirt et al. studied the effects of aggregate size and binder strength on the compressive strength and void ratio of pervious concrete [7]. Chindaprasirt et al. also reported that good porous concretes with void ratio of $15-25 \%$ and strength of $22-39 \mathrm{MPa}$ are produced using paste with flow of $150-230 \mathrm{~mm}$ and top surface vibration of $10 \mathrm{~s}$ with vibrating energy of $90 \mathrm{kN} \mathrm{m} / \mathrm{m}^{2}$ [8].

Neithalath et al. used the values of porosity and the morphologically determined pore sizes, along with the pore phase connectivity represented using an electrical conductivity ratio, in a Katz-Thompson type relationship to predict the permeability of pervious concretes [9]. Lian et al. developed a new model, which was based on the Griffth theory, to predict the compressive strength of pervious concrete using its porosity [10]. Bentz used computer to simulate various virtual pervious concrete microstructural models and compares their percolation characteristics and computed transport properties to those of real world pervious concretes [11].

Putman and Neptune evaluated different pervious concrete test specimen preparation techniques in an effort to produce specimens having properties similar to in-place pervious concrete pavement [12]. Lian and Zhuge studied the optimal mix design for pervious concrete [13]. Kim and Lee studied the influence of cement flow and aggregate type on mechanical and acoustic properties of pervious concrete [14]. Fujiwara et al. reported that a high strength pervious concrete could be made by coating the coarse aggregates with a high-strength mortar, then applying vibration to fuse them [15]. Safiuddin and Hearn compared the permeable porosity obtained from three different ASTM saturation techniques, namely, cold-water saturation (CWS), boilingwater saturation (BWS), and vacuum saturation (VAS). They concluded that vacuum saturation technique is more efficient than cold-water or boiling-water saturation and therefore this technique should be recommended for measuring the permeable porosity of concrete [16]. Haselbach et al. developed a theoretical model between the effective permeability of a sand-clogged pervious concrete block, the permeability of sand, and the porosity of the unclogged block [17]. ThoIn et al. have tried to use alkali-activated high-calcium fly ash to make pervious concrete. They found that the highcalcium fly ash geopolymer binder could be used to produce pervious concrete with satisfactory mechanical properties [18].

In this study, the performance of pervious concrete was investigated by conducting various tests (i.e., mechanical, permeability, soundness, porosity, and unit weight tests) by changing parameters, which include aggregate size and the type, amount, and w/c ratio of binders (for filling the voids among aggregates). However, in addition to featuring excellent water permeability, pervious concrete is expected to exhibit a mechanical performance to a certain level. Generally, once pervious concrete has excellent water permeability then its strength becomes poor. Various strategies can be used to improve the strength of pervious concrete while achieving the required permeability. By altering the parameters of pervious concrete, this study obtained the optimal relationship between strength and water permeability. Subsequently, the required mix proportion was attained through relevant analyses, and different binders were applied to multiple types of pervious concrete to determine the mechanical characteristics and water permeability of pervious concrete. In the experiment, the control group comprised pure cement paste as binding material, and the experiment group involved two types of cement pastes, one containing silica fume and one with alkali-activated slag. The feasibility of enhancing mechanical strength or changes in water permeability can be investigated using different binders.

\section{Experiment Design}

The experiment involved two stages. The first part involved considering three crucial parameters, which were aggregate size, the volume percent of aggregate voids filled with binders, and the w/c ratio of binders, for determining the relationship between water permeability and mechanical strength. Next, the feasibility of enhancing mechanical strength was determined by varying the types of binders used based on the mix proportions obtained from the first part of the experiment. The second stage was aimed at investigating cement pastes containing silica fume and alkali-activated slag. Varying amounts of silica fume were used to replace cement; in other words, cement combined with pozzolanic material was used instead of pure cement paste. Alkaline-activated slag paste with different liquid/slag $(\mathrm{L} / \mathrm{Sg})$ ratios was used to replace the pure cement pastes. Finally, the experiment and control (pure cement paste only) groups were compared to investigate the influences of different binding materials on the properties of pervious cement.

Pervious concrete is primarily composed of aggregates and binding materials, which bind aggregates and fill voids among aggregates to form porous, permeable concrete. 
TABLE 1: Experimental variables of the two-stage experiment.

(a)

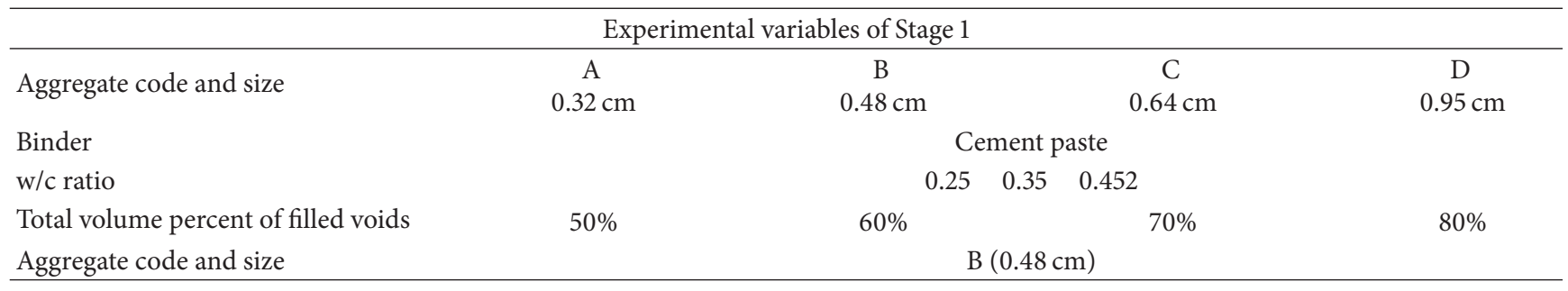

(b)

\begin{tabular}{|c|c|c|c|c|c|}
\hline \multicolumn{6}{|c|}{ Experimental variables of Stage 2} \\
\hline Binder & Alkali-ac & vatec & slag paste & & Silica-fume cement paste \\
\hline Total volume percent of filled voids & & & & $80 \%$ & \\
\hline $\mathrm{L} / \mathrm{Sg}$ or $\mathrm{w} / \mathrm{c}$ ratio & 0.35 & 0.4 & 0.45 & & 0.35 \\
\hline Substitution ratio & & - & & & $10 \% 20 \% 30 \%$ \\
\hline
\end{tabular}

Regarding applications in engineering, pervious concrete should have a certain level of water permeability before its mechanical strength is enhanced. Therefore, designing the void content inside pervious concrete is the key that affects the overall property of the material. High porosity in pervious concrete indicates excellent water permeability but poor mechanical strength because of insufficient compactness. By contrast, low porosity can enhance mechanical strength but might decrease water permeability. Although such judgment can be preliminarily made based on physics concepts, when variables such as binder characteristics and aggregate size are considered, whether or not the effect of porosity on the property of previous concrete conforms to common concepts must be determined by experimental studies. The parameter design concepts are explained as follows.

(i) Aggregate size: in this experiment, uniformly graded aggregates (narrow gradation) were used, which are aggregates of a single size. In addition, aggregate size affects the water permeability and mechanical strength of pervious concrete.

(ii) $\mathrm{W} / \mathrm{c}$ ratio: in pervious concrete, when designing the $\mathrm{w} / \mathrm{c}$ ratios of cement pastes, workability, water permeability, and mechanical strength should be considered. The workability of cement pastes influences the overall performance of pervious concrete.

(iii) The volume percent of aggregate voids filled with binders (hereafter referred to as volume percent of filled voids): this volume percent refers to the amount of binders used in pervious concrete. This amount also influences the water permeability and mechanical strength of pervious concrete.

(iv) Binders: mechanical strength is enhanced by altering binders, which influence the property of pervious concrete.

The binders used in the first stage were cement pastes made by mixing cement with water. Superplasticizers were added to the binder with a low w/c ratio of 0.25 to increase the binder fluidity. In the second stage, cement pastes containing silica fume and alkali-activated slag were used. Based on the first stage of the experiment, the control group involved the following parameters: B aggregate size, w/c ratio of 0.35 , and $80 \%$ volume percent of filled voids. Subsequently, comparison test was conducted in which the mix proportion of binders was altered. The experimental variables are shown in Table 1. In this table, the aggregate size means the minimum size of the sieve grid, for which aggregates pass through the sieve with greater sieve grid and stay in the current one. The total volume percent of filled voids can be understood in the following. First, we packed aggregates inside a unit volume and we could calculate the volume of aggregate by the weight of aggregate and the specific weight of aggregate. Then, we subtracted the total volume by the aggregate volume and obtained the void volume. In such a manner, the total volume percent of filled voids of $50 \%$ means that we use paste to fill $50 \%$ void volume.

2.1. Materials. This study used the Portland Type I cement produced and coarse aggregates of four different sizes as those in Table 1. The aggregates were pebbles and their properties are presented in Table 2.

Superplasticizers are high-performance carboxylic plasticizers. The chemical compositions of sodium silicate, sodium hydroxide, and phosphoric acid used for making alkaliactivated slag paste are shown in Tables 3, 4, and 5. The phosphoric acid is used as the retarder for avoid quick-setting problem of the alkali-activated slag [19].

\subsection{Mix Proportion Design}

2.2.1. The Mix Proportion of Cement Paste as a Binder. We first determined the void volume per unit volume for Types $\mathrm{A}, \mathrm{B}, \mathrm{C}$, and D aggregates as shown in Table 2 . Subsequently, $50 \%, 60 \%, 70 \%$, and $80 \%$ void volumes were filled using cement pastes. In addition, 5\% superplasticizers (by the cement weight) were added to cement pastes with a w/c ratio 
TABLE 2: Physical properties of coarse aggregates.

\begin{tabular}{lcccc}
\hline Code & A & B & C & D \\
Nominal size & $1 / 8 \mathrm{in.}$ & $3 / 16 \mathrm{in.}$ & $1 / 4 \mathrm{in.}$ & $3 / 8 \mathrm{in}$. \\
Maximum size & $0.48 \mathrm{~cm}$ & $0.64 \mathrm{~cm}$ & $0.95 \mathrm{~cm}$ & $0.27 \mathrm{~cm}$ \\
Range of particle sizes & $0.24-0.48 \mathrm{~cm}$ & $0.48-0.64 \mathrm{~cm}$ & $0.64-0.95 \mathrm{~cm}$ & 2.66 \\
Specific gravity & 2.65 & 2.69 & $3.27 \mathrm{~cm}$ \\
Void volume per unit volume & $37.3 \%$ & $37.5 \%$ & $36.8 \%$ & $38.3 \%$ \\
\hline
\end{tabular}

TABLE 3: Chemical composition of sodium silicate.

\begin{tabular}{lc}
\hline Item & Sodium silicate \\
\hline Test item & Test result \\
\hline Insoluble residue & Max. $0.01 \%$ \\
Silicon dioxide (\%) & $37.0 \%$ \\
Sodium oxide (\%) & $17.7 \%$ \\
Mole ratio & 2.16 \\
Iron $(\mathrm{Fe})$ & Max. $0.02 \%$ \\
\hline
\end{tabular}

TABLE 4: Chemical composition of sodium hydroxide.

\begin{tabular}{lc}
\hline Test item & Test results \\
\hline Chloride $(\mathrm{Cl})$ & Max. $0.005 \%$ \\
Sulfate $\left(\mathrm{SO}_{4}\right)$ & Max. $0.003 \%$ \\
Silicate $\left(\mathrm{SiO}_{2}\right)$ & Max. $0.01 \%$ \\
Phosphate $\left(\mathrm{PO}_{4}\right)$ & Max. $0.001 \%$ \\
Heavy metals $($ arsenic and lead) & Max. $0.001 \%$ \\
Iron $(\mathrm{Fe})$ & Max. $0.0007 \%$ \\
Aluminum $(\mathrm{Al})$ & Max. $0.003 \%$ \\
Calcium $(\mathrm{Ca})$ & Max. $0.001 \%$ \\
Magnesium $(\mathrm{Mg})$ & Max. $0.0005 \%$ \\
Potassium $(\mathrm{K})$ & Max. $0.1 \%$ \\
Total nitrogen $(\mathrm{N})$ & Max. $0.001 \%$ \\
Arsenic $(\mathrm{As})$ & Max. $0.0002 \%$ \\
Sodium carbonate $\left(\mathrm{Na}_{2} \mathrm{CO}_{3}\right)$ & Max. $2.0 \%$ \\
Assay $(\mathrm{NaOH})$ & Max. $95.0 \%$ \\
\hline
\end{tabular}

of 0.25 to enhance fluidity. The mix proportion design is shown in Table 6.

2.2.2. The Mix Proportion of Alkali-Activated Slag Paste as a Binder. The alkali activator was made by first adding sodium hydroxide to sodium silicate and then mixing the mixture uniformly before phosphoric acid (retarder) was added. The mix proportion design is shown in Table 7 . In this table, the L/Sg ratio means the weight ratio between liquid phase activator and slag. The activator was made by mixing the hydroxide and sodium silicate and to reach the concentration $\mathrm{SiO}_{2}=106 \mathrm{~g} / \mathrm{L}$ and $\mathrm{Na}_{2} \mathrm{O}=105 \mathrm{~g} / \mathrm{L}$. And the retarder was phosphoric acid of $0.74 \mathrm{M}$.

\subsubsection{The Mix Proportion of Silica-Fume Cement Paste as a} Binder. Table 8 shows the mix proportion design for silicafume cement paste; the substitution percentages for silica fume were $10 \%, 20 \%$, and $30 \%$ of the cement weight.
TABLE 5: Chemical composition of phosphoric acid.

\begin{tabular}{lc}
\hline Item & Phosphoric acid \\
\hline Test item & Test results \\
\hline Chloride $(\mathrm{Cl})$ & Max. $0.001 \%$ \\
Nitrate $\left(\mathrm{NO}_{3}\right)$ & To pass test \\
Sulfate $\left(\mathrm{SO}_{4}\right)$ & Max. $0.006 \%$ \\
Alkali and other phosphates (sulfate) & To pass test \\
Substances reducing $\mathrm{KMnO}_{4}$ & To pass test \\
Heavy metals (As and $\mathrm{Pb})$ & Max. $0.001 \%$ \\
Iron $(\mathrm{Fe})$ & Max. $0.005 \%$ \\
Arsenic $($ As) & Max. $0.0003 \%$ \\
Specific gravity & $1.700-1.710$ \\
Assay & Max. $85.0 \%$ \\
\hline
\end{tabular}

\subsection{Tests}

(1) Porosity test: the total porosity in pervious concrete includes disconnected porosity and connected porosity, which is the primary influencing factor of water permeability. A caliper was used to measure and calculate specimen volume $V_{1}$; the specimen was immersed in water until it is filled with water before its weight in water $W_{1}$ is measured. Subsequently, the specimen was taken out of water and dried, and then its weight in air $W_{2}$ when its weight is stable was measured. The equation for connected porosity $P_{1}$ is as follows:

$$
P_{1}=\left[1-\frac{\left(W_{2}-W_{1}\right)}{V_{1}}\right] * 100 \%
$$

(2) Unit weight: after the pervious concrete specimens solidified and were demolded, they were dried in an oven at $105 \pm 5^{\circ} \mathrm{C}$ until their weights were stable. The specimens were weighed and analyzed using a caliper to measure, calculate, and obtain their volumes. Dividing the weight by volume yields the weight of pervious concrete per unit volume.

(3) Compressive strength: compressive strength was determined based on the ASTM C39 for cylindrical concrete specimens.

(4) Flexural strength: flexural strength was determined based on the three-point bending test.

(5) Splitting tensile strength: this test was performed for determining the splitting tensile strength of cylindrical concrete specimens. 
TABLE 6: Testing proportions of cement pastes as a binder.

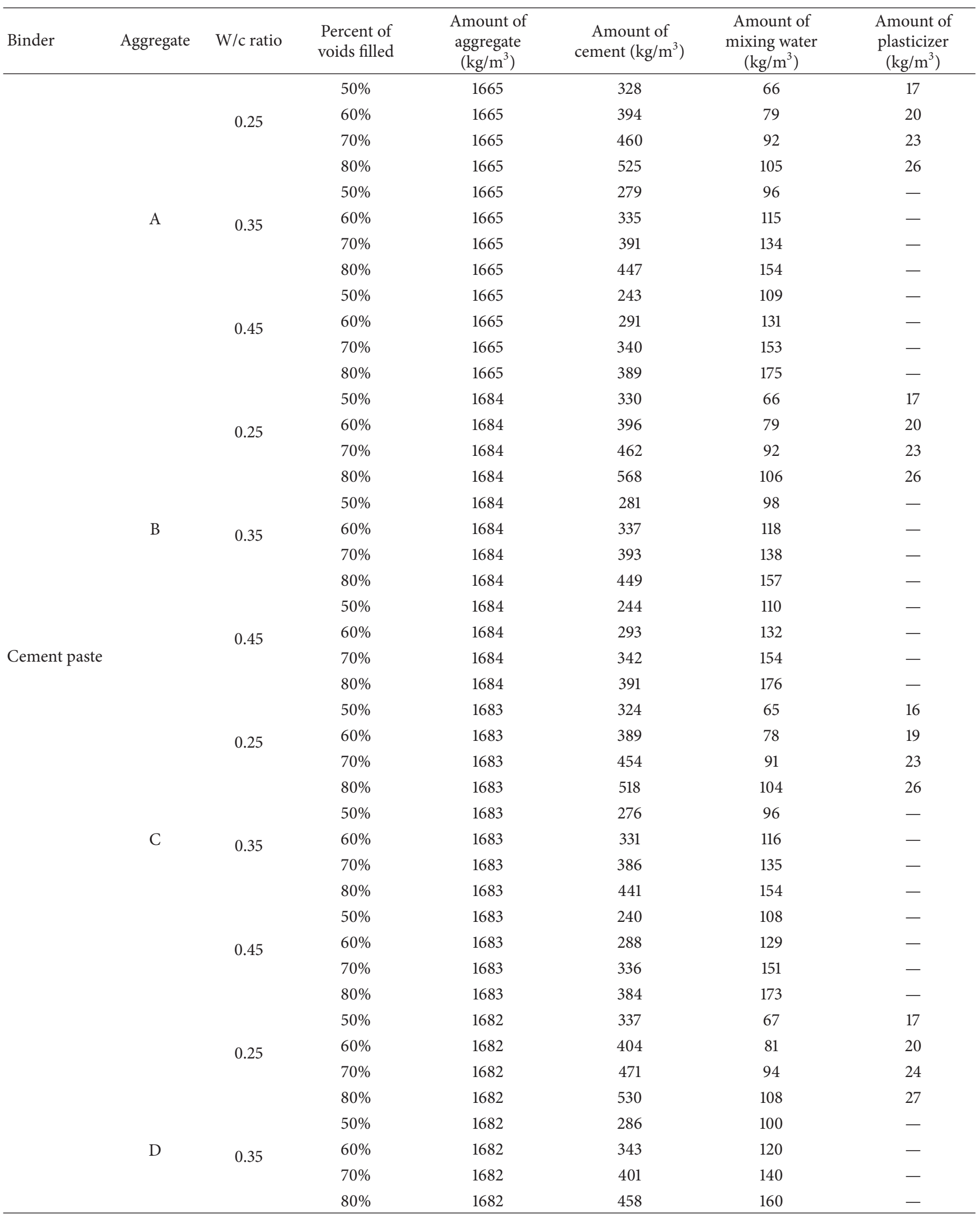


TABLE 6: Continued.

\begin{tabular}{|c|c|c|c|c|c|c|c|}
\hline Binder & Aggregate & $\mathrm{W} / \mathrm{c}$ ratio & $\begin{array}{l}\text { Percent of } \\
\text { voids filled }\end{array}$ & $\begin{array}{c}\text { Amount of } \\
\text { aggregate } \\
\left(\mathrm{kg} / \mathrm{m}^{3}\right)\end{array}$ & $\begin{array}{c}\text { Amount of } \\
\text { cement }\left(\mathrm{kg} / \mathrm{m}^{3}\right)\end{array}$ & $\begin{array}{c}\text { Amount of } \\
\text { mixing water } \\
\left(\mathrm{kg} / \mathrm{m}^{3}\right)\end{array}$ & $\begin{array}{c}\text { Amount of } \\
\text { plasticizer } \\
\left(\mathrm{kg} / \mathrm{m}^{3}\right)\end{array}$ \\
\hline & & \multirow{4}{*}{0.45} & $50 \%$ & 1682 & 249 & 112 & - \\
\hline & & & $60 \%$ & 1682 & 299 & 134 & - \\
\hline & & & $70 \%$ & 1682 & 349 & 157 & - \\
\hline & & & $80 \%$ & 1682 & 398 & 179 & - \\
\hline
\end{tabular}

TABLE 7: The mix proportion of alkali-activated slag paste.

\begin{tabular}{|c|c|c|c|}
\hline $\mathrm{L} / \mathrm{Sg}$ & 0.35 & 0.40 & 0.45 \\
\hline Aggregate size & & $\mathrm{B}$ & \\
\hline Volume percent of filled voids & & $80 \%$ & \\
\hline Concentration of alkali activator & $\mathrm{SiO}_{2}=106 \mathrm{~g} / \mathrm{L}$ & & $\mathrm{Na}_{2} \mathrm{O}=105 \mathrm{~g} / \mathrm{L}$ \\
\hline Amount of phosphoric acid & & $0.74 \mathrm{M}$ & \\
\hline Amount of slag $\left(\mathrm{kg} / \mathrm{m}^{3}\right)$ & 432 & 403 & 377 \\
\hline Amount of alkali-activated solution $\left(\mathrm{kg} / \mathrm{m}^{3}\right)$ & 151 & 161 & 170 \\
\hline Amount of aggregate $\left(\mathrm{kg} / \mathrm{m}^{3}\right)$ & 1684 & 1684 & 1684 \\
\hline
\end{tabular}

TABLE 8: The mix proportion of silica-fume cement paste.

\begin{tabular}{|c|c|c|c|}
\hline Proportion of cement replaced by silica fume & $10 \%$ & $20 \%$ & $30 \%$ \\
\hline Aggregate size & & B & \\
\hline Volume percent of filled voids & & $80 \%$ & \\
\hline Amount of cement $\left(\mathrm{kg} / \mathrm{m}^{3}\right)$ & 404 & 359 & 314 \\
\hline Amount of silica fume $\left(\mathrm{kg} / \mathrm{m}^{3}\right)$ & 39 & 78 & 118 \\
\hline Amount of mixing water $\left(\mathrm{kg} / \mathrm{m}^{3}\right)$ & 155 & 153 & 151 \\
\hline Amount of aggregate $\left(\mathrm{kg} / \mathrm{m}^{3}\right)$ & & 1684 & \\
\hline
\end{tabular}

(6) Water permeability coefficient: the water permeability coefficient was calculated using the constant-head permeability test, which is based on the Pavement Test Manual established by the Japan Road Association. The permeability instrument measured the permeability coefficient of $\Phi 10 * 20 \mathrm{~cm}$ cylindrical specimens. The equation for water permeability coefficient $K$ is expressed as follows:

$$
K=\frac{Q L}{A H \Delta t},
$$

where $K$ is water permeability coefficient $(\mathrm{cm} / \mathrm{s}), Q$ is flow volume $(\mathrm{mL}), L$ is specimen thickness $(\mathrm{cm}), A$ is the pervious surface area of specimens $\left(\mathrm{cm}^{2}\right), H$ is water head height $(\mathrm{cm})$, and $\Delta t=t_{1}-t_{0}$ represents time duration of measurement (s).

(7) Soundness test: aggregate soundness tests using magnesium sulfate were employed. Specimens were placed in an oven at $110 \pm 5^{\circ} \mathrm{C}$ to dry until the constant weight $W_{1}$ was obtained. After cooled to room temperature, the specimen was fully immersed (liquid rising $13 \mathrm{~mm}$ above the top of the specimen) for at least $16 \mathrm{~h}$ but less than $18 \mathrm{~h}$ in an oversaturated magnesium sulfate solution. After immersion, the specimen was taken out of the solution, washed using clean water, and then dried until the constant weight $W_{2}$ was obtained. The equation for calculating specimen weight-loss percentage is expressed as follows:

$$
\text { Weight loss } \%=\frac{w_{1}-w_{2}}{w_{1}} \times 100 \%
$$

\section{Test Results and Analysis}

3.1. Unit Weight Test. Because pervious concrete has numerous voids, its unit weight is slightly lighter than those of common concrete. Regarding the mix proportion of cement pastes, changes in unit weight were observed based on a fixed aggregate size. The unit weight increased with the amount of binders but decreased with the increase of w/c ratios as shown in Figures 1(a)-1(d). Comparing the influence of different binders on unit weight, the unit weight of alkali-activated slag 


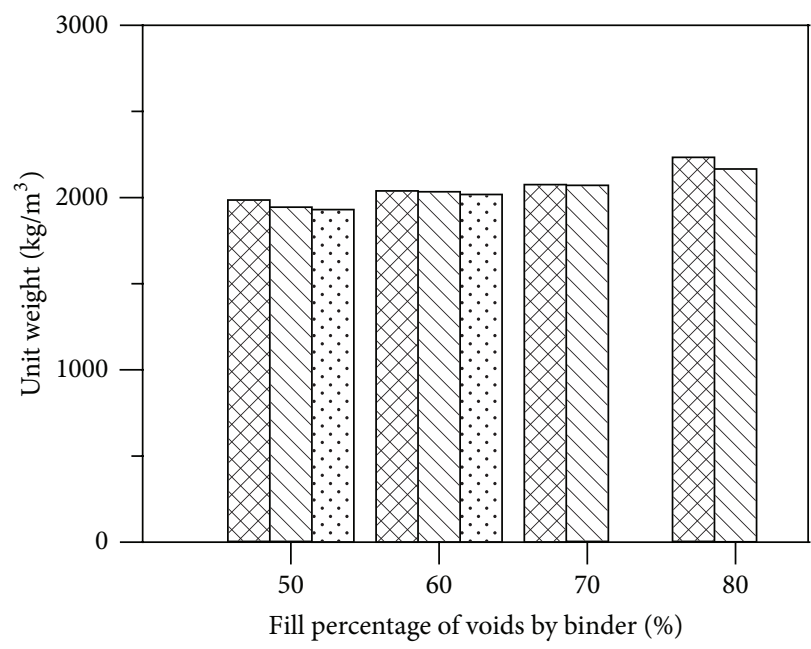

Particle A

$\square \times B$ Binder $w / c=0.25$

$\square$ Binder $\mathrm{w} / \mathrm{c}=0.35$

$\because$ Binder $\mathrm{w} / \mathrm{c}=0.45$

(a) Unit weights for particle A

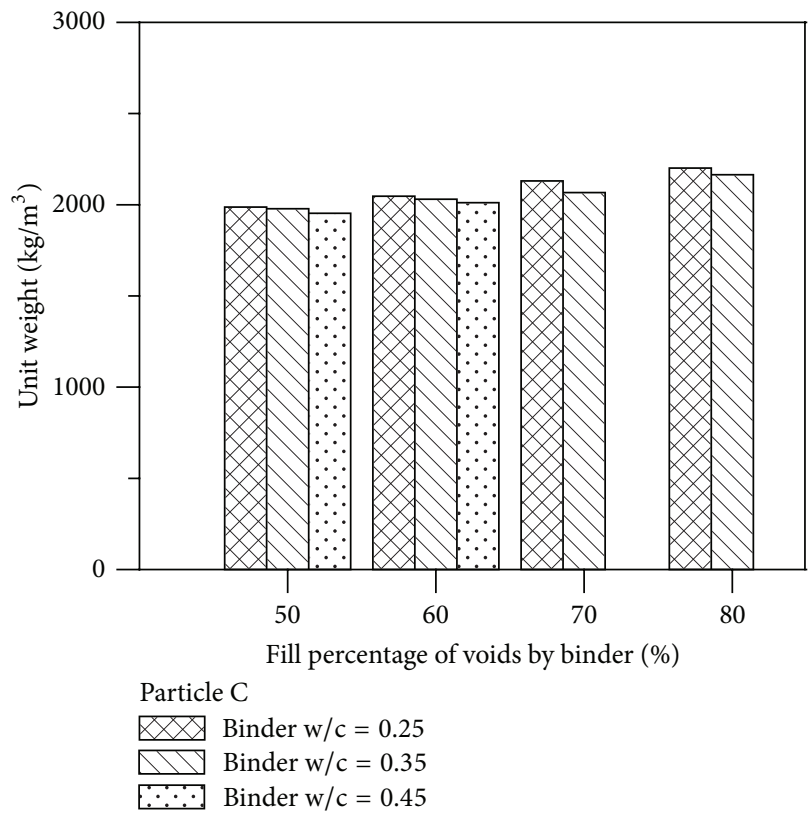

(c) Unit weights for particle C

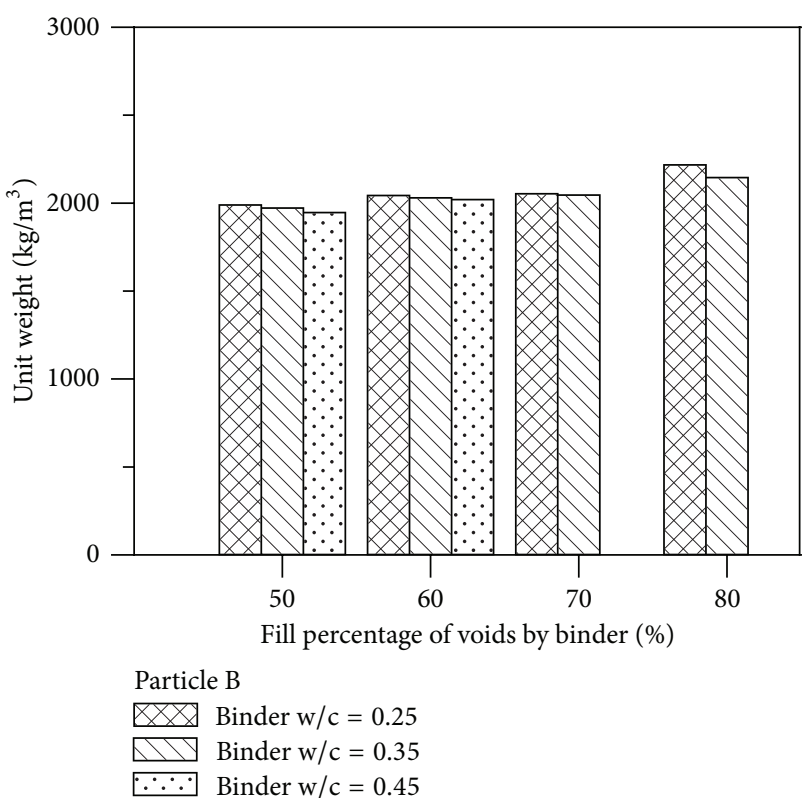

(b) Unit weights for particle B

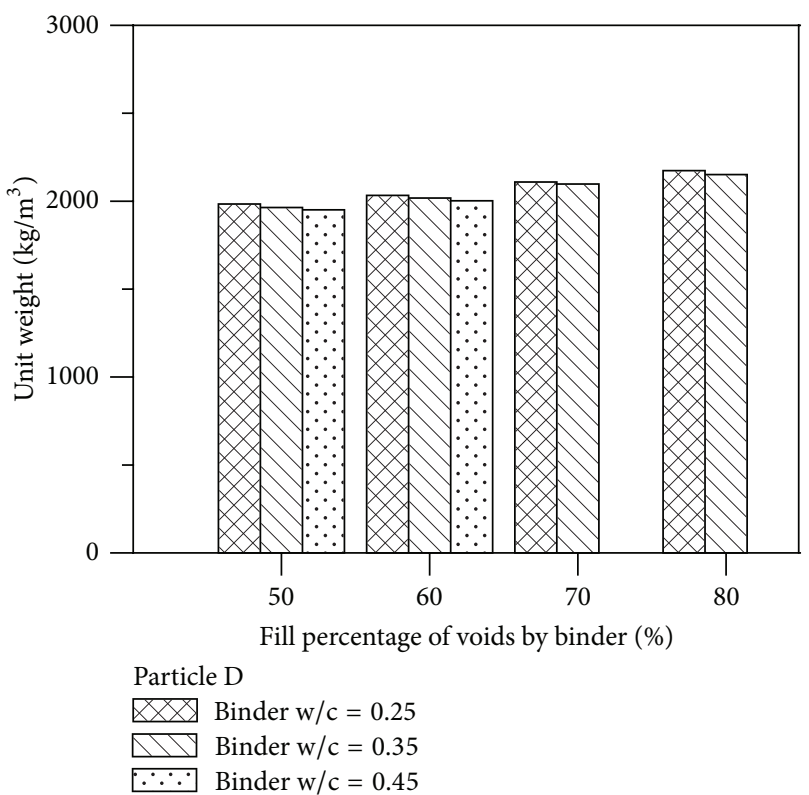

(d) Unit weights for particle D

FIGURE 1: Unit weight of specimens comprising various particle sizes.

paste was greater than that of the control specimen $(\mathrm{w} / \mathrm{c}=$ 0.35 ; aggregate code $=B$; volume percent of filled voids $=80 \%$; binder = Portland cement paste), whereas the unit weight of the silica-fume cement paste was smaller than that of control specimen. In addition, the unit weights of specimens decreased as the amount of silica fume increased.

3.2. Permeability Test. Table 9 shows the water permeability coefficients of the specimens with different mix proportions. The specimen label is explained in the following. The first two digits represent the $\mathrm{w} / \mathrm{c}$ ratio (Portland cement paste) or $\mathrm{L} / \mathrm{Sg}$ ratio (alkali-activated slag paste) or $\mathrm{w} / \mathrm{b}$ ratio (silica-fume modified Portland cement paste). The alphabet followed the two digits means the aggregate code $(\mathrm{A}, \mathrm{B}, \mathrm{C}$, and $\mathrm{D})$. The next two digits mean the volume percent of filled voids. After these, the remaining characters mean the binder type (C stands for cement paste; A stands for the alkali-activated slag paste; S1 stands for silica-fume modified cement paste with the replacement percentage of 10\%; S2 stands for silicafume modified cement paste with the replacement percentage 
TABLE 9: The water permeability coefficients for various mix proportions.

\begin{tabular}{|c|c|c|c|c|c|c|c|}
\hline Label & $K(\mathrm{~cm} / \mathrm{sec})$ & Label & $K(\mathrm{~cm} / \mathrm{sec})$ & Label & $K(\mathrm{~cm} / \mathrm{sec})$ & Label & $K(\mathrm{~cm} / \mathrm{sec})$ \\
\hline $25 \mathrm{~A} 50 \mathrm{C}$ & 0.1140 & $35 \mathrm{~A} 50 \mathrm{C}$ & 0.0997 & $45 \mathrm{~A} 50 \mathrm{C}$ & 0.0881 & $35 \mathrm{~B} 80 \mathrm{~A}$ & 0.0430 \\
\hline $25 \mathrm{~A} 60 \mathrm{C}$ & 0.1052 & $35 \mathrm{~A} 60 \mathrm{C}$ & 0.0555 & $45 \mathrm{~A} 60 \mathrm{C}$ & 0.0464 & $40 \mathrm{~B} 80 \mathrm{~A}$ & 0.0446 \\
\hline $25 \mathrm{~A} 70 \mathrm{C}$ & 0.0852 & $35 \mathrm{~A} 70 \mathrm{C}$ & 0.0323 & $45 \mathrm{~A} 70 \mathrm{C}$ & NA & $45 \mathrm{~B} 80 \mathrm{~A}$ & 0.0421 \\
\hline $25 \mathrm{~A} 80 \mathrm{C}$ & 0.0436 & $35 \mathrm{~A} 80 \mathrm{C}$ & 0.0304 & $45 \mathrm{~A} 80 \mathrm{C}$ & NA & $35 \mathrm{~B} 80 \mathrm{~S} 1$ & 0.0454 \\
\hline 25B50C & 0.1259 & $35 \mathrm{~B} 50 \mathrm{C}$ & 0.1192 & 45B50C & 0.1176 & $35 \mathrm{~B} 80 \mathrm{~S} 2$ & 0.0441 \\
\hline $25 \mathrm{~B} 60 \mathrm{C}$ & 0.1163 & $35 \mathrm{~B} 60 \mathrm{C}$ & 0.1044 & $45 \mathrm{~B} 60 \mathrm{C}$ & 0.0925 & $35 \mathrm{~B} 80 \mathrm{~S} 3$ & 0.0444 \\
\hline 25B70C & 0.0864 & 35B70C & 0.0585 & $45 \mathrm{~B} 70 \mathrm{C}$ & NA & & \\
\hline $25 B 80 C$ & 0.0857 & $35 \mathrm{~B} 80 \mathrm{C}$ & 0.0439 & $45 \mathrm{~B} 80 \mathrm{C}$ & NA & & \\
\hline $25 \mathrm{C} 50 \mathrm{C}$ & 0.1423 & $35 \mathrm{C} 50 \mathrm{C}$ & 0.1273 & 45C50C & 0.1210 & & \\
\hline $25 \mathrm{C} 60 \mathrm{C}$ & 0.1283 & $35 \mathrm{C} 60 \mathrm{C}$ & 0.1199 & $45 \mathrm{C} 60 \mathrm{C}$ & 0.1097 & & \\
\hline $25 \mathrm{C} 70 \mathrm{C}$ & 0.1185 & $35 \mathrm{C} 70 \mathrm{C}$ & 0.1118 & $45 \mathrm{C} 70 \mathrm{C}$ & NA & & \\
\hline $25 \mathrm{C} 80 \mathrm{C}$ & 0.1126 & $35 \mathrm{C} 80 \mathrm{C}$ & 0.1046 & $45 \mathrm{C} 80 \mathrm{C}$ & NA & & \\
\hline $25 \mathrm{D} 50 \mathrm{C}$ & 0.1440 & $35 \mathrm{D} 50 \mathrm{C}$ & 0.1355 & $45 \mathrm{D} 50 \mathrm{C}$ & 0.1331 & & \\
\hline 25D60C & 0.1350 & $35 \mathrm{D} 60 \mathrm{C}$ & 0.1292 & $45 \mathrm{D} 60 \mathrm{C}$ & 0.1283 & & \\
\hline $25 \mathrm{D} 70 \mathrm{C}$ & 0.1284 & $35 \mathrm{D} 70 \mathrm{C}$ & 0.1131 & $45 \mathrm{D} 70 \mathrm{C}$ & NA & & \\
\hline $25 \mathrm{D} 80 \mathrm{C}$ & 0.1149 & $35 \mathrm{D} 80 \mathrm{C}$ & 0.1105 & 45D80C & NA & & \\
\hline
\end{tabular}

of 20\%; and S3 stands for silica-fume modified cement paste with the replacement percentage of $30 \%)$. For example, the label 25A50C means $\mathrm{w} / \mathrm{c}=0.25$; aggregate code $=$ A; volume percentage of filled voids $=50 \%$; and binder $=$ cement paste. In Table 9, there exist some specimens without permeability coefficients. The sagging phenomenon, which means that the cement paste does not stick to the aggregate and sags to the bottom of specimen due to its gravity, was observed. Once the sagging phenomenon happens, the paste will not be uniformly distributed around aggregates and will be accumulated in the bottom of specimen due to the gravity. Consequently, the water permeability will dramatically decrease since on the cross-section near the bottom the permeability is low. Based on this, we discard the records of these specimens. This result indicated that for $\mathrm{w} / \mathrm{c}=$ 0.45 , the viscosity enhancer should be introduced to avoid the possible sagging phenomenon.

The mix proportion of particle $\mathrm{D}$ exhibited an optimal water permeability coefficient $K$. Specifically, the specimen $25 \mathrm{D} 50 \mathrm{C}$ with aggregate $\mathrm{D}, \mathrm{w} / \mathrm{c}$ ratio of 0.25 , and $50 \%$ binderfilled voids had the greatest coefficient $K$ of $0.1440 \mathrm{~cm} / \mathrm{sec}$. However, the specimen $35 \mathrm{~A} 80 \mathrm{C}$ with particle $\mathrm{A}, \mathrm{w} / \mathrm{c}$ ratio of 0.35 , and $80 \%$ binder-filled voids had the smallest coefficient $K$ of 0.0304 . Figures 2(a)-2(d) show the graphs comparing the particle size variables based on data from Table 5.

For the different aggregate sizes, the water permeability coefficients decreased as binder $w / c$ ratios increased. This is because at low w/c ratio, binders are highly viscous, enabling the binder to fully cover the aggregates. Intact and fully covered aggregate forms after specimens solidified, and point-topoint contact among the aggregates remains, yielding a void structure that forms a path for water permeation. By contrast, with high w/c ratios, because binders have great fluidity, excess binders that cannot cover aggregates may block the path, thereby decreasing water permeability.

In addition, as the aggregate size increased, the water permeability of pervious concrete increased. For the conventional concrete, three phases (mortar, interface transition zone, and coarse aggregates) exist. The interface transition zone (ITZ) has the worst property among these three phases. It means that the mechanical strength of ITZ is weakest and the water permeability of ITZ is highest since the microstructure of ITZ contains more microcracks, voids, and so on. Therefore, it is well known that the ITZ dominates the behaviors of conventional concrete. If the volume fraction of ITZ increases, a lower compressive strength and a higher permeability coefficient then are expected. Consequently, as the aggregate size was smaller, the volume fraction of ITZ was expected to be larger. It then becomes very puzzling why the water permeability coefficient increased as the aggregate size increased. The reason is explained as the following. For the pervious concrete, four phases (paste, ITZ, coarse aggregates, and designed porosity) exist. Unlike the conventional concrete which adopts mortar to fill the space between aggregates, we only partially fill the space between aggregates by binder for pervious concrete. This concept intentionally makes some porosity inside concrete in order to allow water penetration. Among these four phases, the designed porosity has the worst properties. It has no mechanical strength at all and highest water permeation coefficient. Therefore, the volume fraction of the porosity dominates the behaviors of pervious concrete. When aggregate size is smaller, the initial porosity after packing is smaller. Consequently, when the volume percent of filled voids is the same, the remaining porosity for pervious concrete made with smaller size aggregates is smaller. Therefore, the water permeability coefficient becomes lower. 


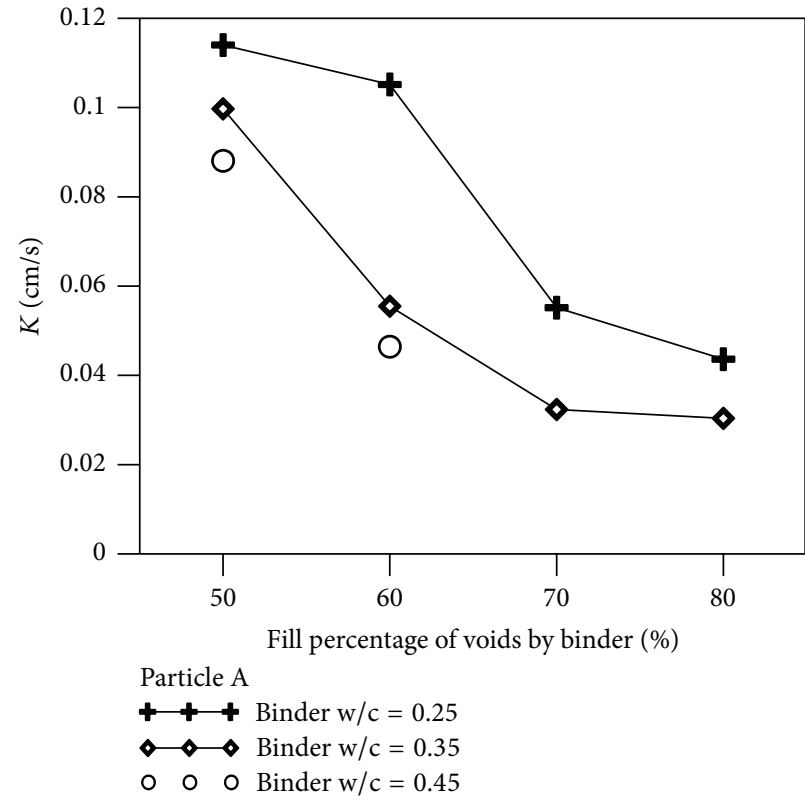

(a)

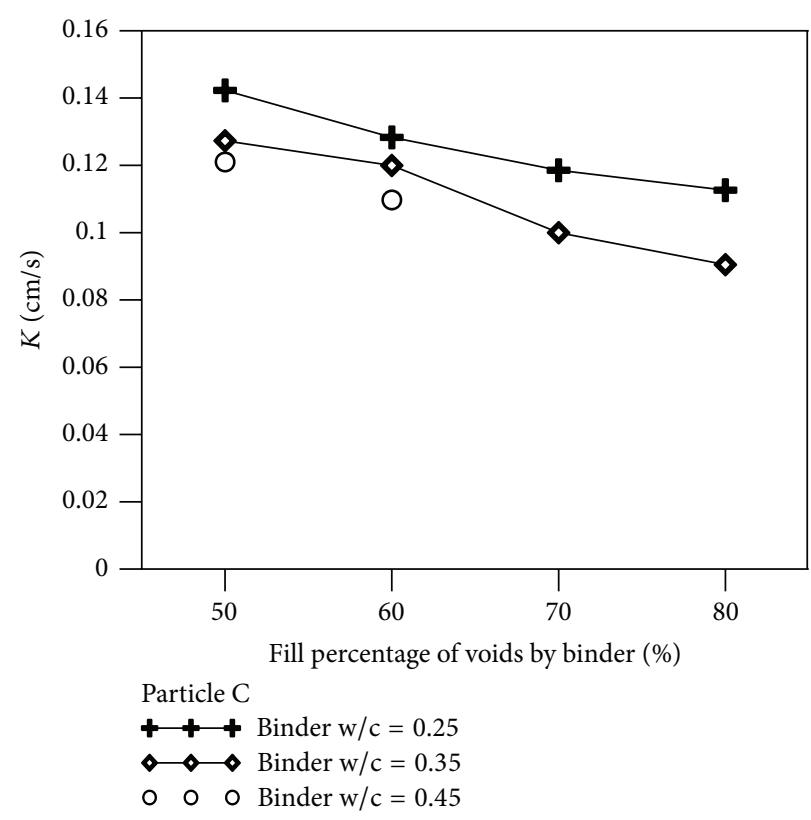

(c)

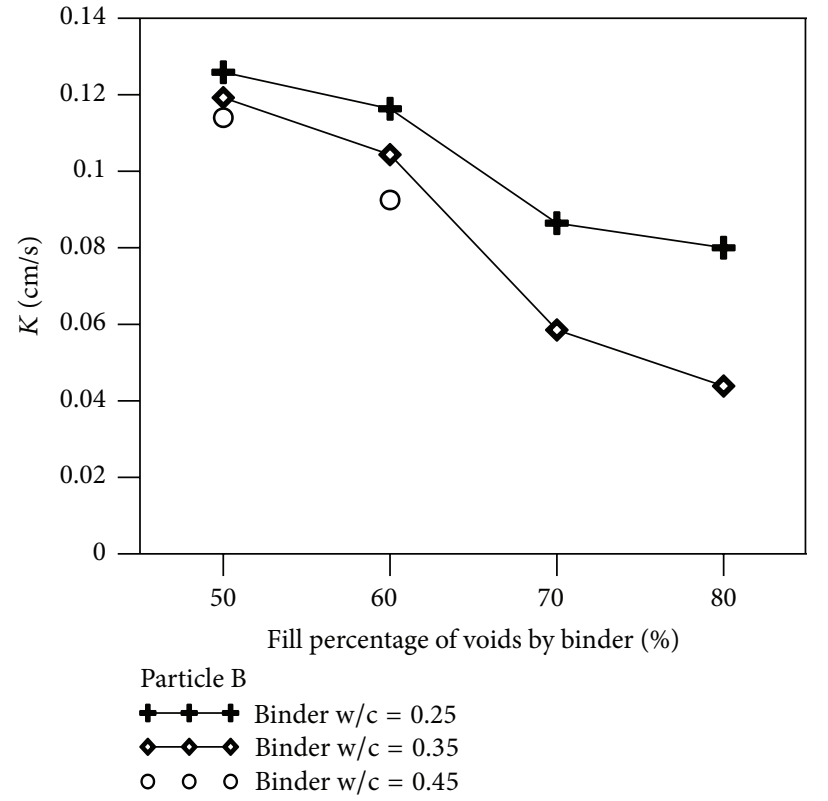

(b)

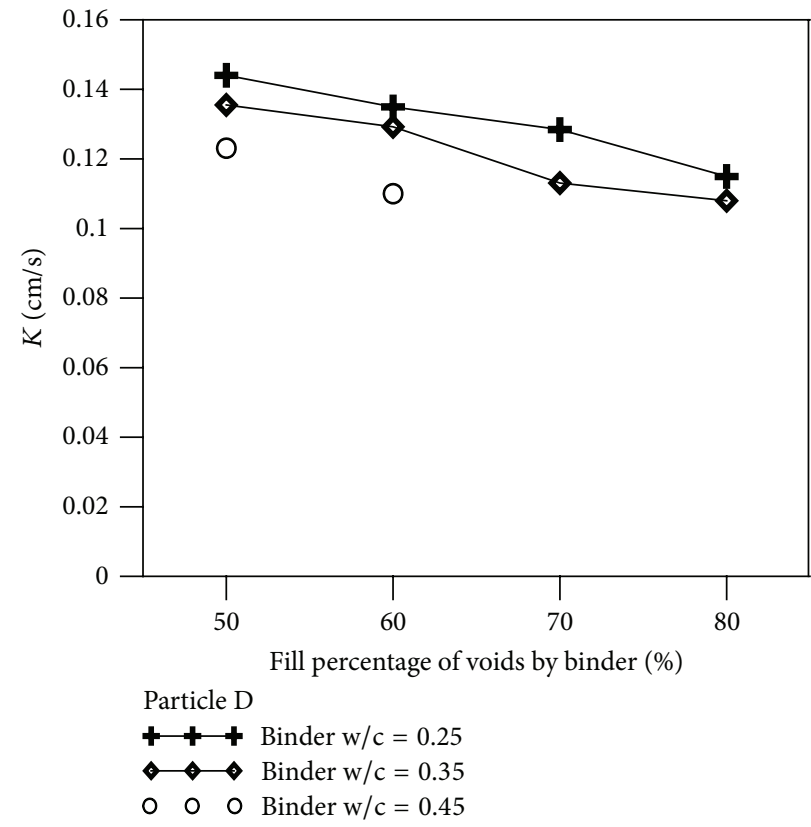

(d)

FIGURE 2: Water permeability coefficients of specimens comprising different aggregate sizes: (a) aggregate A; (b) aggregate B; (c) aggregate C; (d) aggregate $\mathrm{D}$.

3.3. Porosity Test. The internal structure of pervious concrete is relatively less compact because using an insufficient amount of binders produces voids. Water permeability is primarily affected by connected porosity, which can be measured through experimental tests. As shown in Figures 3(a)-3(d), a fixed trend was observed when other parameters were compared based on the various mix proportions. The porosity in pervious concrete is typically inversely proportional to the amount of binders used. Basically, the trends for the values of connected porosity were similar to those for water permeability coefficient. It is worth mentioning here that the connected porosity increased as the aggregate size increased. The reason has been mentioned in the previous subsection. Once again, the dominating factor is the total voids inside pervious concrete but not the ITZ.

3.4. Compressive Strength Test. Table 10 shows the results of 28-day compressive strength tests for various mix 
TABLE 10: The results of the compressive strength test.

\begin{tabular}{|c|c|c|c|c|c|c|c|}
\hline Label & $\begin{array}{c}\text { Compressive } \\
\text { strength }(\mathrm{MPa})\end{array}$ & Label & $\begin{array}{c}\text { Compressive } \\
\text { strength }(\mathrm{MPa})\end{array}$ & Label & $\begin{array}{c}\text { Compressive } \\
\text { strength }(\mathrm{MPa})\end{array}$ & Label & $\begin{array}{c}\text { Compressive } \\
\text { strength }(\mathrm{MPa})\end{array}$ \\
\hline $25 \mathrm{~A} 50 \mathrm{C}$ & 17.49 & $35 \mathrm{~A} 50 \mathrm{C}$ & 12.30 & $45 \mathrm{~A} 50 \mathrm{C}$ & 10.62 & $35 \mathrm{~B} 80 \mathrm{~A}$ & 28.73 \\
\hline $25 \mathrm{~A} 60 \mathrm{C}$ & 19.01 & $35 \mathrm{~A} 60 \mathrm{C}$ & 16.01 & $45 \mathrm{~A} 60 \mathrm{C}$ & 14.83 & $40 \mathrm{~B} 80 \mathrm{~A}$ & 24.98 \\
\hline $25 \mathrm{~A} 70 \mathrm{C}$ & 22.61 & $35 \mathrm{~A} 70 \mathrm{C}$ & 20.95 & 45A70C & - & $45 \mathrm{~B} 80 \mathrm{~A}$ & 17.49 \\
\hline $25 \mathrm{~A} 80 \mathrm{C}$ & 25.67 & $35 \mathrm{~A} 80 \mathrm{C}$ & 24.94 & $45 \mathrm{~A} 80 \mathrm{C}$ & - & $35 \mathrm{~B} 80 \mathrm{~S} 1$ & 21.98 \\
\hline 25B50C & 17.07 & 35B50C & 11.87 & $45 \mathrm{~B} 50 \mathrm{C}$ & 8.74 & $35 \mathrm{~B} 80 \mathrm{~S} 2$ & 15.43 \\
\hline $25 \mathrm{~B} 60 \mathrm{C}$ & 17.45 & $35 \mathrm{~B} 60 \mathrm{C}$ & 14.49 & $45 \mathrm{~B} 60 \mathrm{C}$ & 11.62 & $35 \mathrm{~B} 80 \mathrm{~S} 3$ & 7.68 \\
\hline $25 \mathrm{~B} 70 \mathrm{C}$ & 20.36 & $35 \mathrm{~B} 70 \mathrm{C}$ & 18.81 & $45 \mathrm{~B} 70 \mathrm{C}$ & - & & \\
\hline 25B80C & 21.95 & 35B80C & 20.86 & 45B80C & - & & \\
\hline $25 \mathrm{C} 50 \mathrm{C}$ & 16.26 & $35 \mathrm{C} 50 \mathrm{C}$ & 11.24 & $45 \mathrm{C} 50 \mathrm{C}$ & 7.49 & & \\
\hline $25 \mathrm{C} 60 \mathrm{C}$ & 16.86 & $35 \mathrm{C} 60 \mathrm{C}$ & 13.18 & $45 \mathrm{C} 60 \mathrm{C}$ & 9.49 & & \\
\hline 25C70C & 20.01 & $35 \mathrm{C} 70 \mathrm{C}$ & 15.51 & 45C70C & - & & \\
\hline $25 \mathrm{C} 80 \mathrm{C}$ & 21.38 & $35 \mathrm{C} 80 \mathrm{C}$ & 16.49 & $45 \mathrm{C} 80 \mathrm{C}$ & - & & \\
\hline $25 \mathrm{D} 50 \mathrm{C}$ & 13.45 & $35 \mathrm{D} 50 \mathrm{C}$ & 10.34 & $45 \mathrm{D} 50 \mathrm{C}$ & 5.62 & & \\
\hline $25 \mathrm{D} 60 \mathrm{C}$ & 13.68 & $35 \mathrm{D} 60 \mathrm{C}$ & 11.87 & $45 \mathrm{D} 60 \mathrm{C}$ & 7.93 & & \\
\hline 25D70C & 17.32 & $35 \mathrm{D} 70 \mathrm{C}$ & 14.86 & $45 \mathrm{D} 70 \mathrm{C}$ & - & & \\
\hline 25D80C & 19.20 & $35 \mathrm{D} 80 \mathrm{C}$ & 15.61 & $45 \mathrm{D} 80 \mathrm{C}$ & - & & \\
\hline
\end{tabular}

proportions. The alkali-activated slag paste (35B80A) yielded the highest compressive strength of $28.73 \mathrm{MPa}$, and the cement paste (45D50C) yielded the smallest strength of 5.62 MPa. After compiling the data obtained from Table 6, Figures 4(a)-4(b) were plotted, displaying a comparison of the parameters based on fixed particle sizes.

It can be found that the compressive strength decreased as the aggregate size increased. Similar results were also found for other mechanical properties such as splitting tensile strength test and flexural strength test. As explained above, for the conventional concrete, the property of ITZ dominates the property of concrete since ITZ plays as the weakest part in concrete. However, for pervious concrete the weakest part now is designed void. As an increase in aggregate size, a higher volume of void then is expected under the same condition. In such a manner, the compressive strength decreased. Similar result has been observed in [4].

3.5. Splitting Tensile Strength Test. Figures 5(a)-5(d) show the results of the splitting tensile strength tests. The alkaliactivated slag paste (35B80A) yielded the highest splitting tensile strength of $3.19 \mathrm{MPa}$, and the cement paste (45D50C) yielded the smallest strength of $1.21 \mathrm{MPa}$. According to Figures $5(\mathrm{a})-5(\mathrm{~d})$, the binder with a w/c ratio of 0.25 had the greatest splitting tensile strength, whereas the binder with a w/c ratio of 0.45 had the weakest splitting tensile strength. Therefore, the w/c ratios of binders influence splitting tensile strength. In addition, using a substantial amount of binder strengthened splitting tensile strength; moreover, the specimens with $80 \%$ binder-filled voids yielded the highest splitting tensile strength.

Furthermore, the splitting tensile strength decreased as the aggregate size increased. The reason has been given in Section 3.4.
3.6. Flexural Strength Test. Figures 6(a)-6(d) present the results of flexural strength tests. Specimen 35B80C exhibited the highest flexural strength at $4.76 \mathrm{MPa}$, and specimen 45D50C produced the weakest flexural strength of $2.18 \mathrm{MPa}$. The figures show that flexural strength is directly proportional to the amount of binder used. In addition, the flexural strength of binders with low w/c ratio is superior to that of high-w/c ratio binders. Thus, the mix proportions with highest flexural strengths had a w/c ratio of 0.25 and $80 \%$ binder-filled voids, and those with weakest flexural strengths had a w/c ratio of 0.45 and $50 \%$ binder-filled voids. In addition, the flexural strength decreased as the aggregate size increased. The reason has been given in Section 3.4.

3.7. Soundness Test. Soundness tests can simulate the resistance of pervious concrete specimens to sulfate attacks. In this study, 12-day old specimens were immersed in an oversaturated magnesium sulfate solution and then washed before subjecting to a round robin test. Subsequently, the weight loss percentages of the specimens were measured to infer the resistance to sulfate attacks; the results are shown in Figures 7(a)-7(d). Specimen 35B80S3, which comprised cement paste and $30 \%$ silica fume, exhibited a great weight loss percentage of $3 \%$, and the alkali-activated slag specimen 35B80A yielded a minimal weight loss percentage of $0.57 \%$.

For all the aggregate sizes, maximum weight loss occurred with $50 \%$ binder-filled void, and weight loss increased as the amount of binder used increased. Regarding binder characteristics, weight loss was minimal at a w/c ratio of 0.25 and increased with increasing $\mathrm{w} / \mathrm{c}$ ratio. This was caused by the overall compactness of the specimen. When a small amount of binder was used, increased number of voids in the specimen became available for sulfate attacks and reactions between cements and aggregates. As with w/c ratios, after 


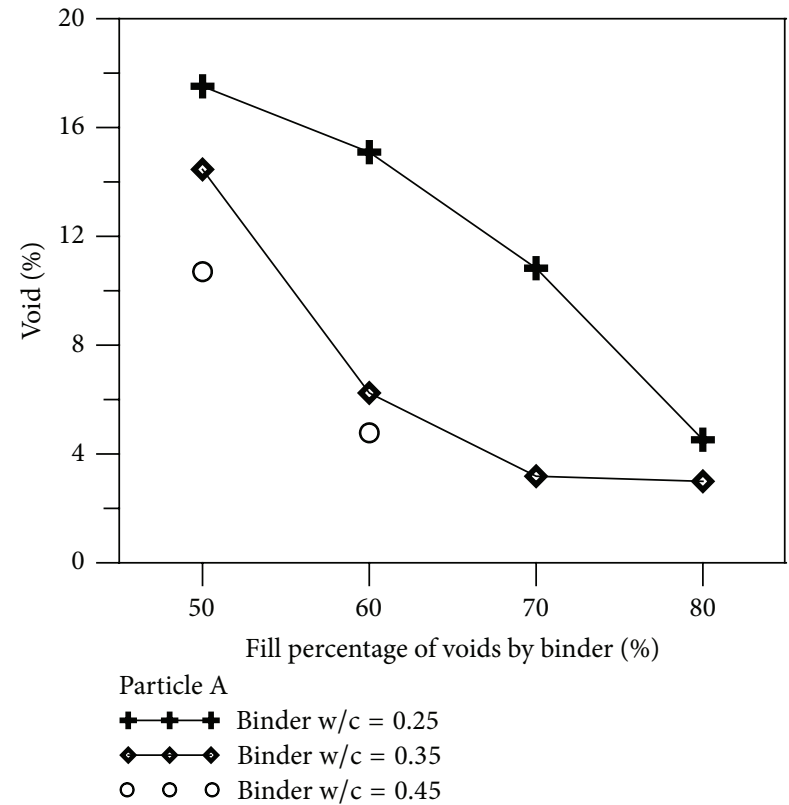

(a)

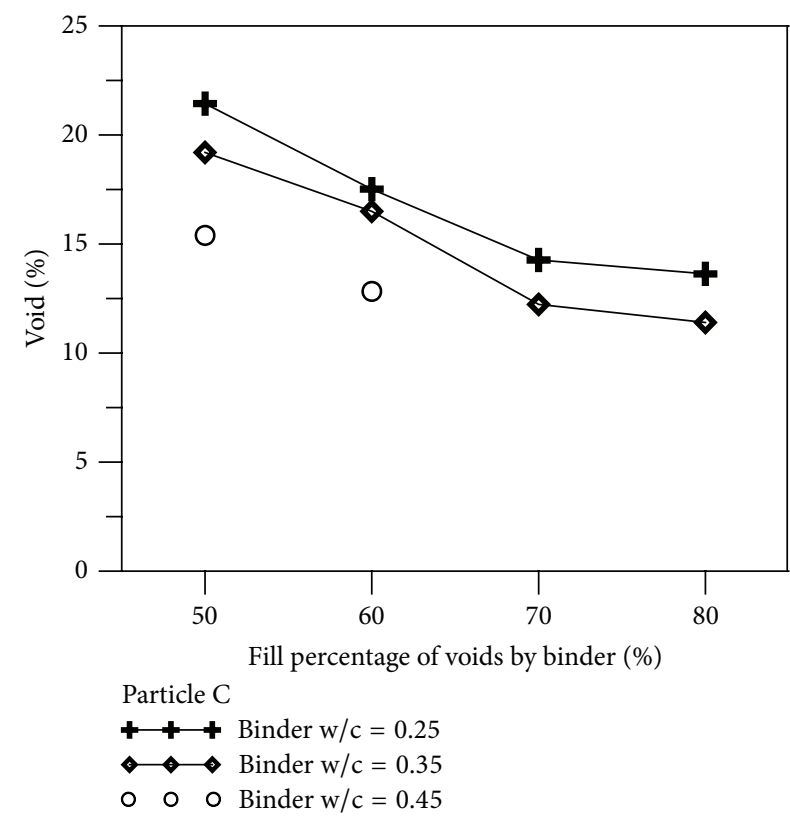

(c)

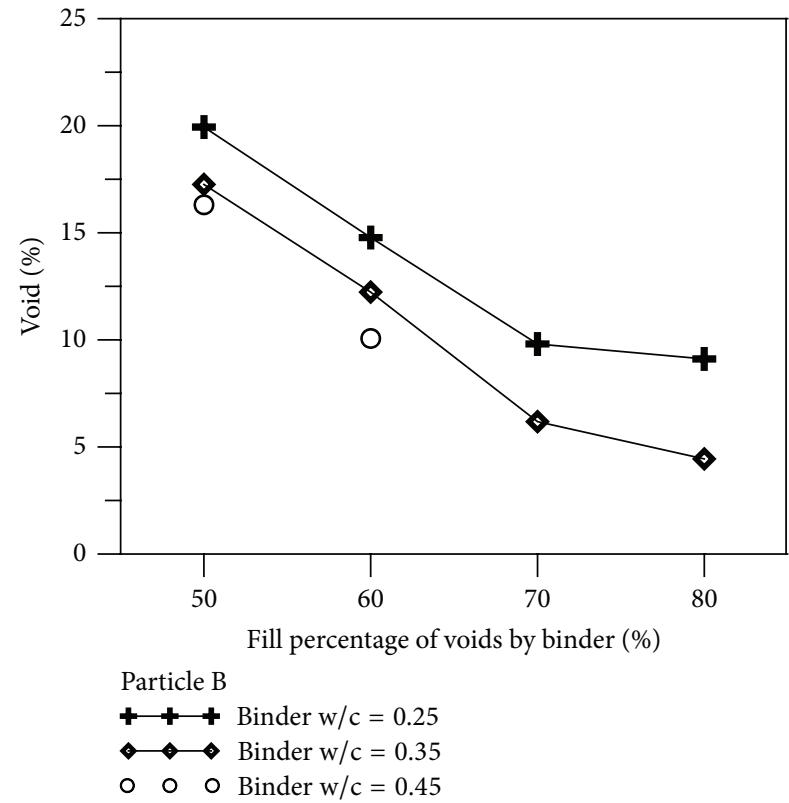

(b)

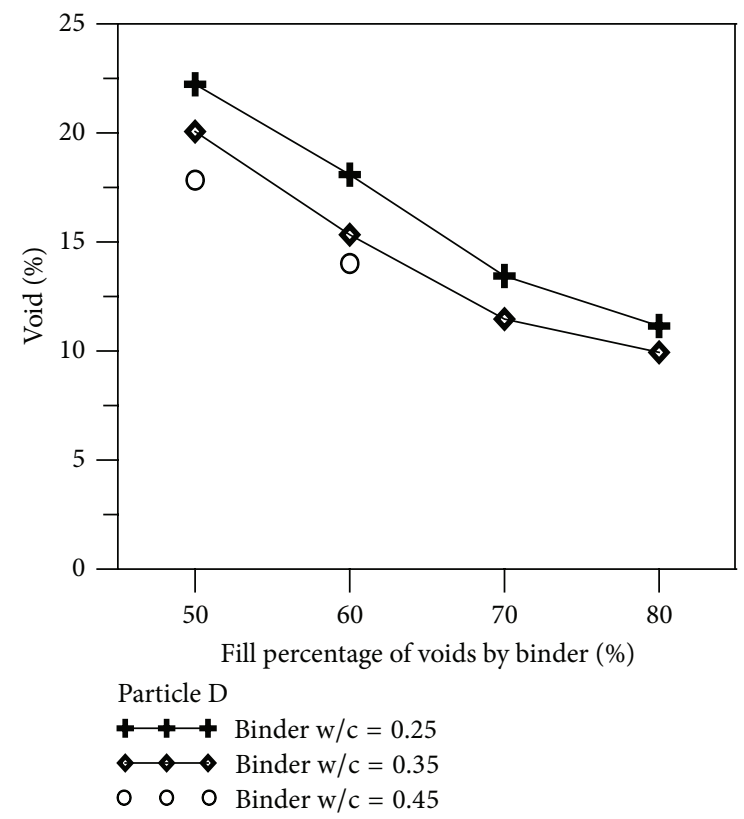

(d)

FIGURE 3: Connected porosity of specimens comprising different aggregate sizes: (a) aggregate A; (b) aggregate B; (c) aggregate C; (d) aggregate D.

high-w/c binders solidified, the amount of small voids that remained after water loss or hydration was greater than that of low-w/c binders. This increase in void amount created paths for sulfate attacks, thus decreasing the sulfate-attack resistance of high-w/c pervious concrete containing low amount of binders.

3.8. The Cross-Comparison of Water Permeability Coefficients. The specimens comprising four various aggregate sizes were subjected to permeability and connected porosity tests. The test results were then used to plot an $X-Y$ distribution graph to which trend lines were added as shown in Figure 8. For the four types of particle sizes, water permeability coefficient $K$ was directly proportional to connected porosity. Next, an analysis on water permeability coefficients based on a fixed porosity was conducted, which revealed a directly proportional relationship between permeability and aggregate size. From a physics point of view, a fixed porosity should only correspond with a specific permeability coefficient, which contradicts the results of this study, in which 


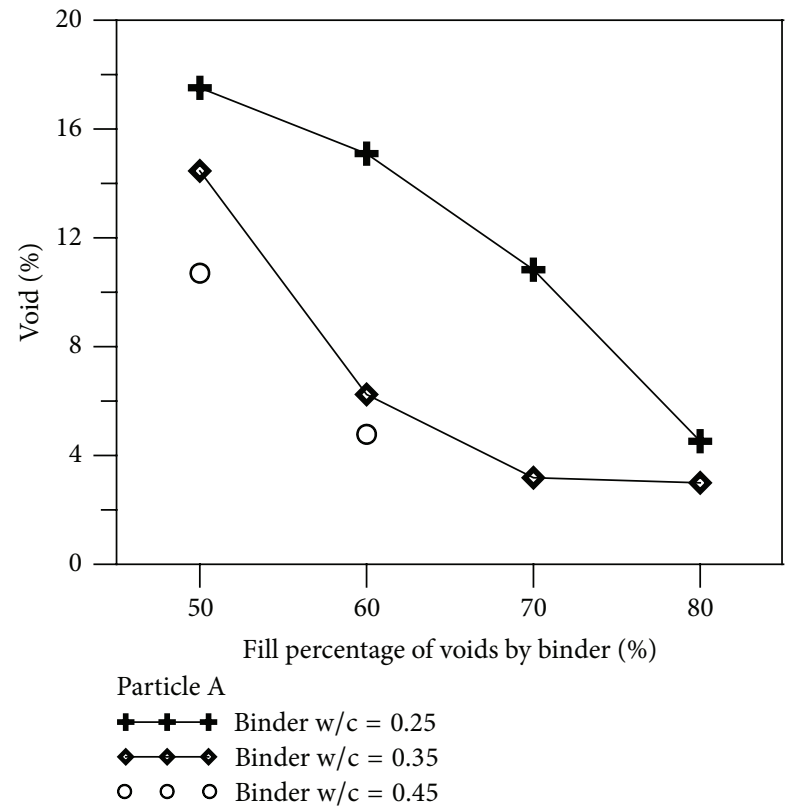

(a)

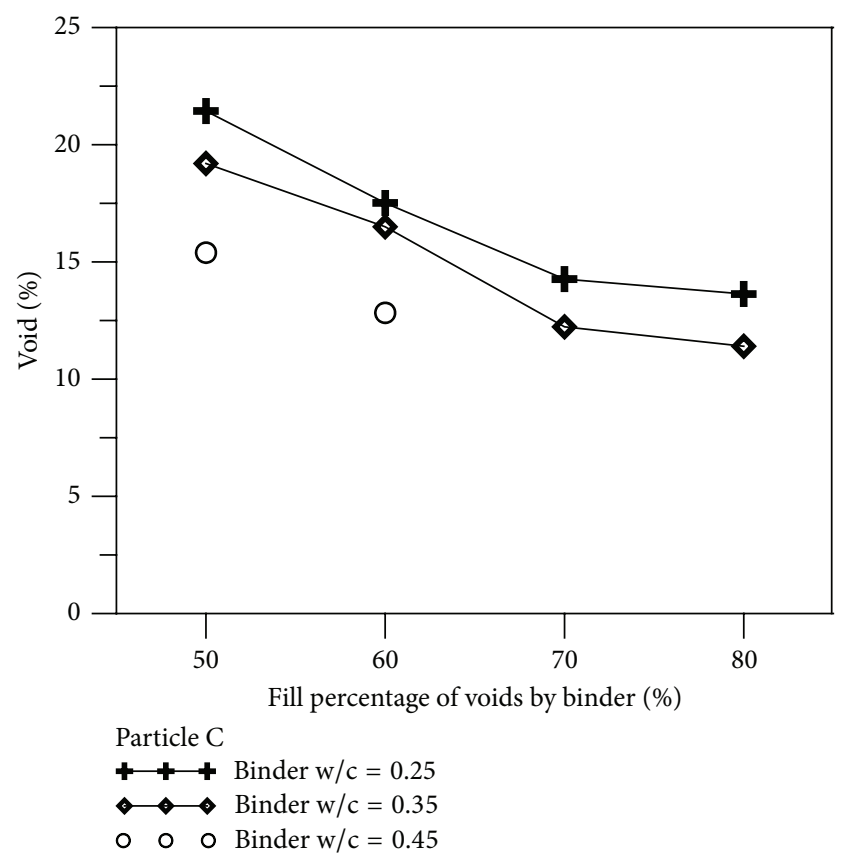

(c)

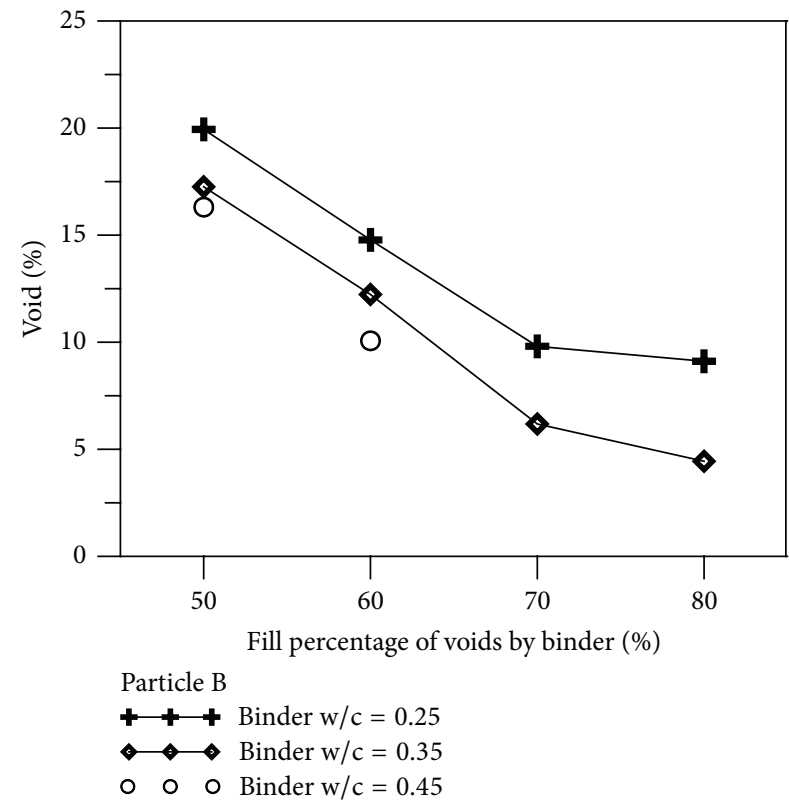

(b)

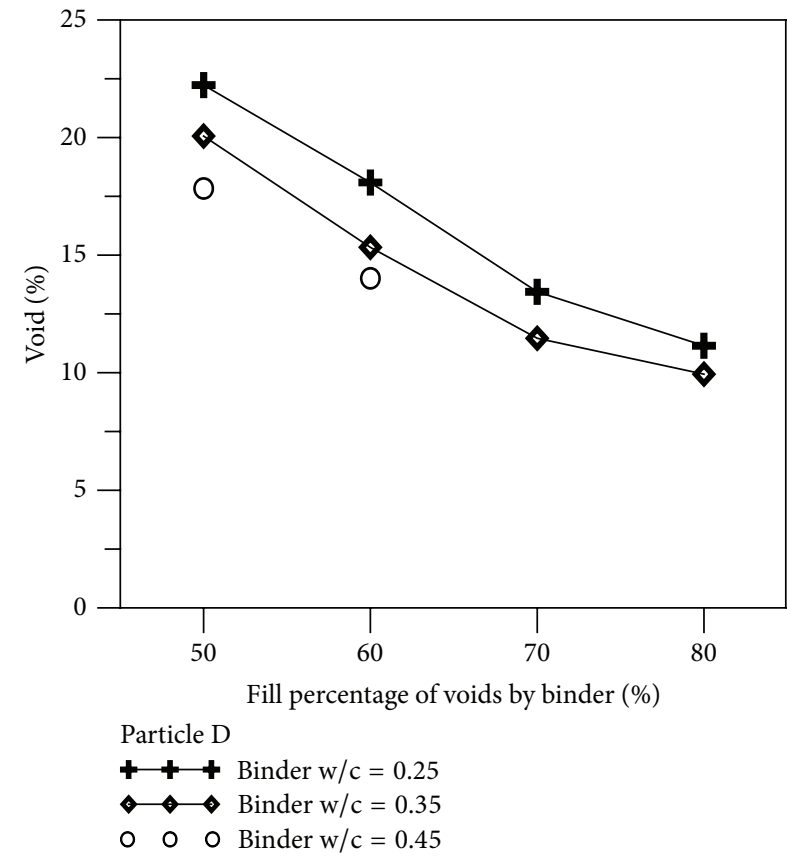

(d)

FIGURE 4: Compressive strengths of specimens comprising different aggregate sizes: (a) aggregate A; (b) aggregate B; (c) aggregate C; (d) aggregate D.

multiple coefficients were observed. The reason might be that although the specimens had the same porosity under certain conditions, the void sizes differ depending on the aggregate size. Under identical connected porosity, the specimens with small aggregates had small sectional areas in the connected voids, generating meandering paths for water permeation. Conversely, specimens consisting of large particles had large sectional areas and, thus, had straight paths. Therefore, the velocity $(V)$ of the water infiltrated in the specimen differed, yielding variation in the flow volume $(Q)$ of the water flowing out of the specimen.

To determine the correlation between compressive strength and water permeability, these two variables were measured for each particle size and then an $X-Y$ distribution graph was plotted. Trend lines were added to the graph to illustrate the correlation. Figure 9 shows that mechanical 


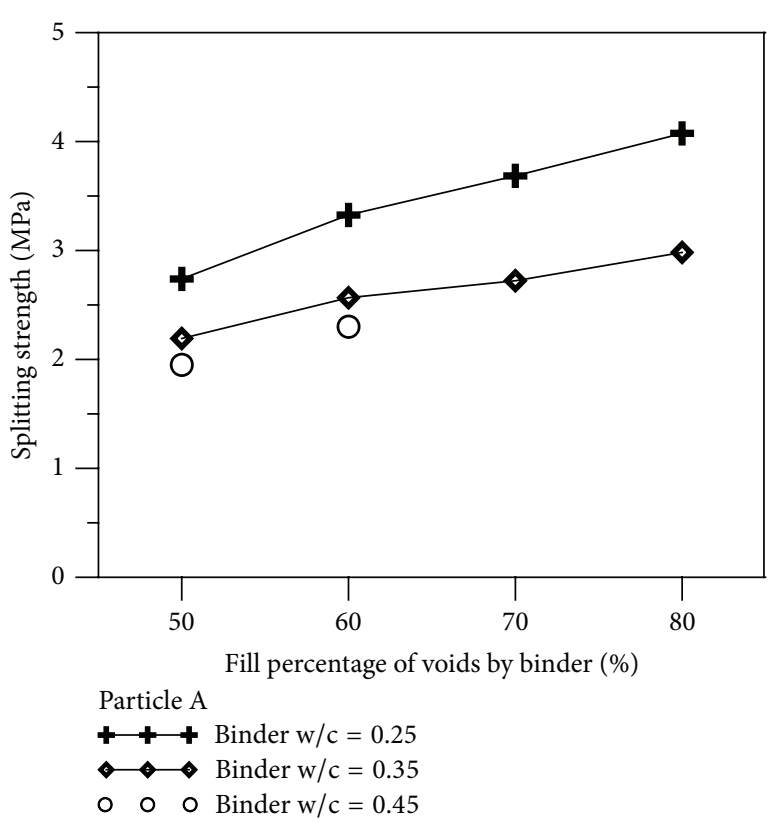

(a)

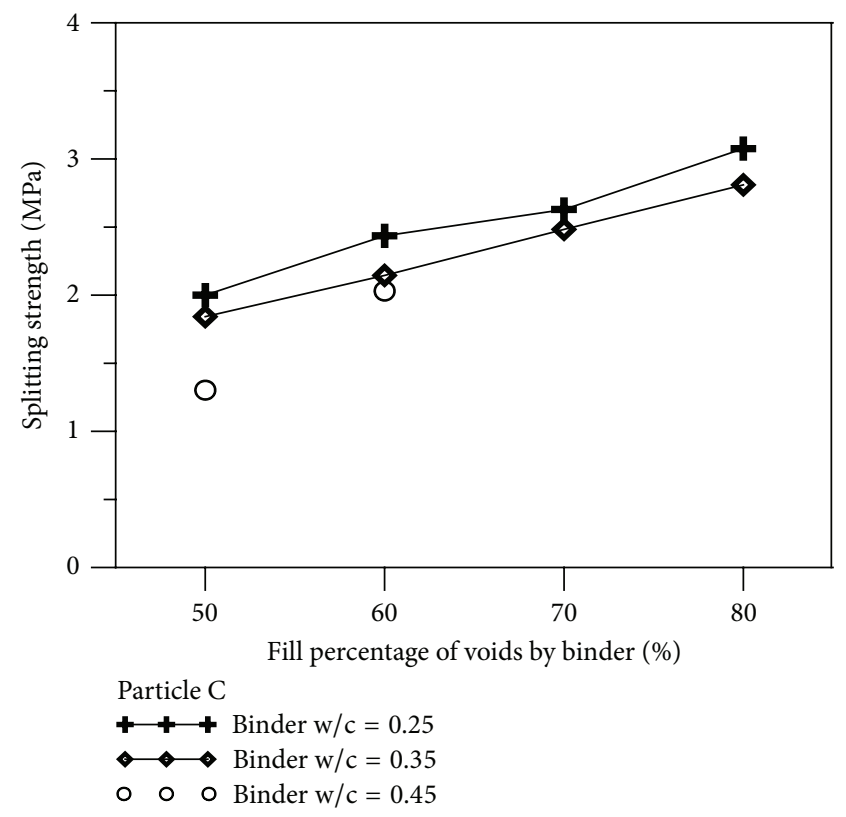

(c)

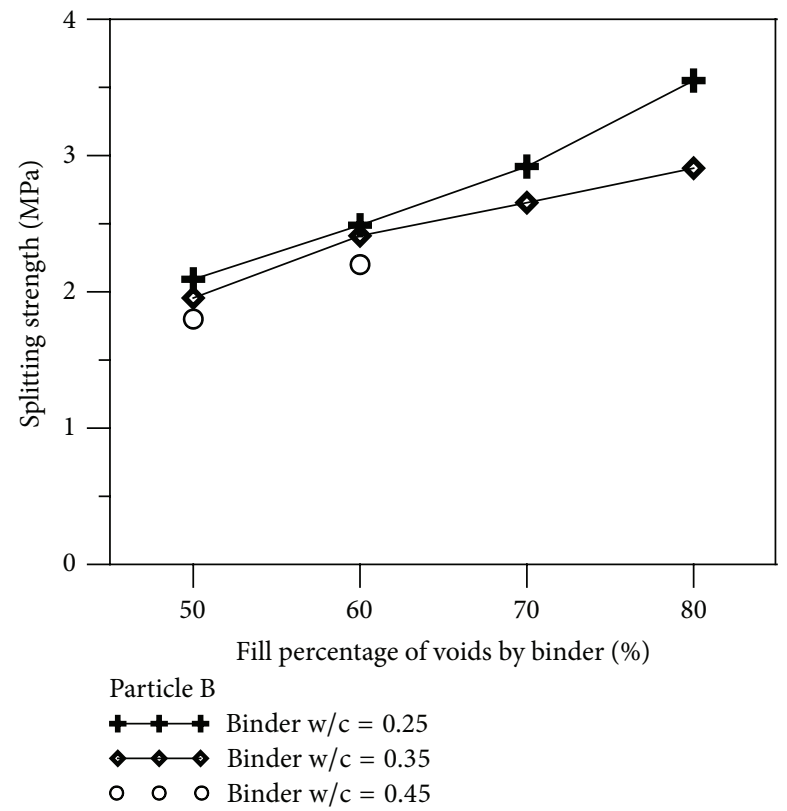

(b)

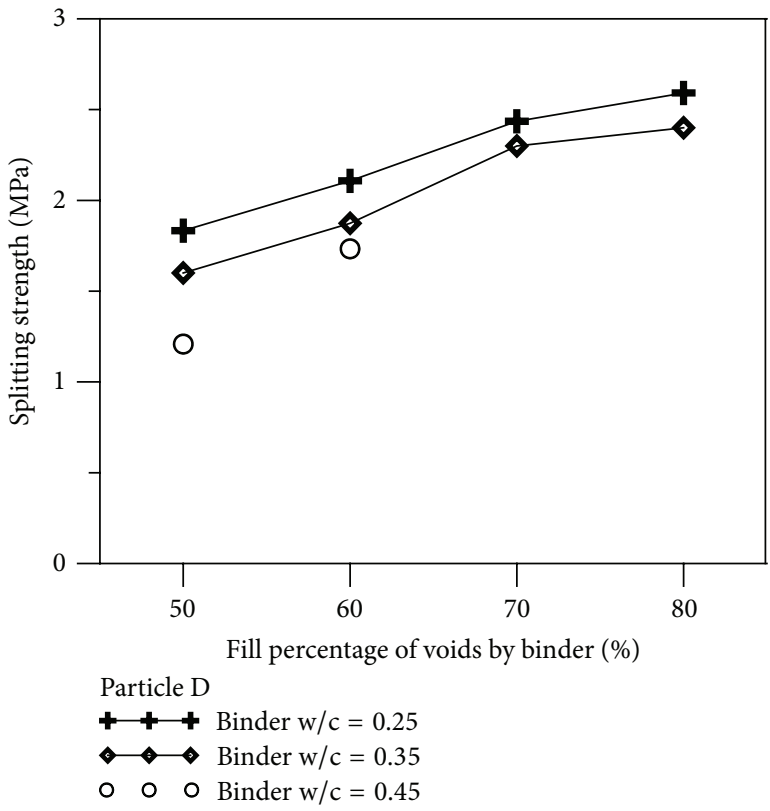

(d)

FIGURE 5: Splitting tensile strengths of specimens comprising different aggregate sizes: (a) aggregate A; (b) aggregate B; (c) aggregate C; (d) aggregate $\mathrm{D}$.

strength decreases as water permeability coefficient increases, and such relationship is applicable for all aggregate sizes.

\section{Conclusions}

(1) Water permeability coefficient and connected porosity decreased with the increase of binder amounts but increased with increasing aggregate size.
(2) Pervious concrete with binders of low w/c ratio is highly viscous, which facilitated covering the aggregates. This enabled sufficient binding between particles and effectively reduced excess binders from blocking water permeation paths, thereby influencing water permeability.

(3) Under identical connected porosity, the specimens with small particles had small sectional areas in the connected voids, producing meandering paths 


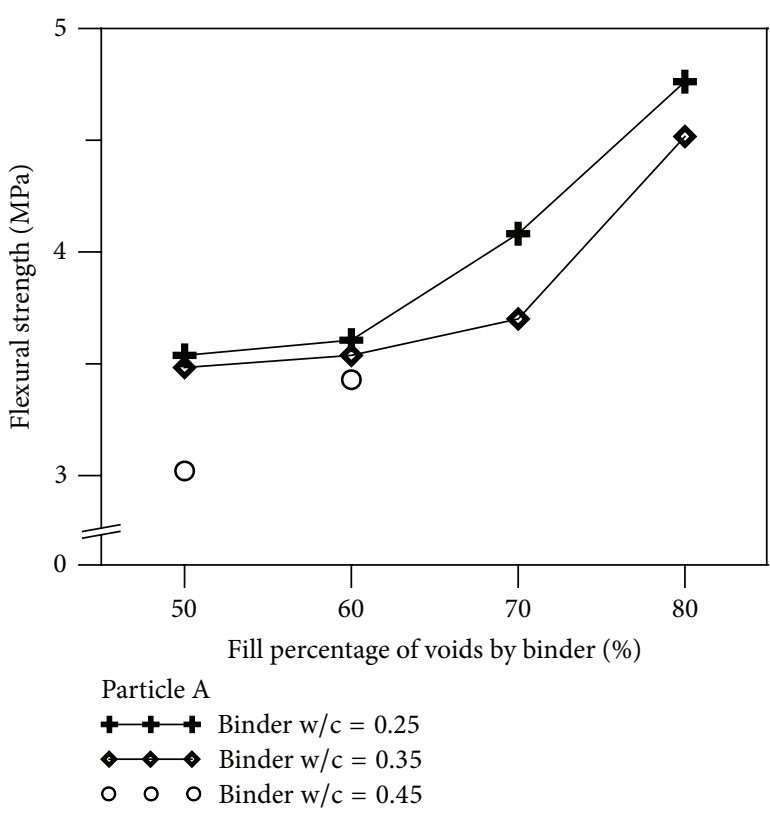

(a)

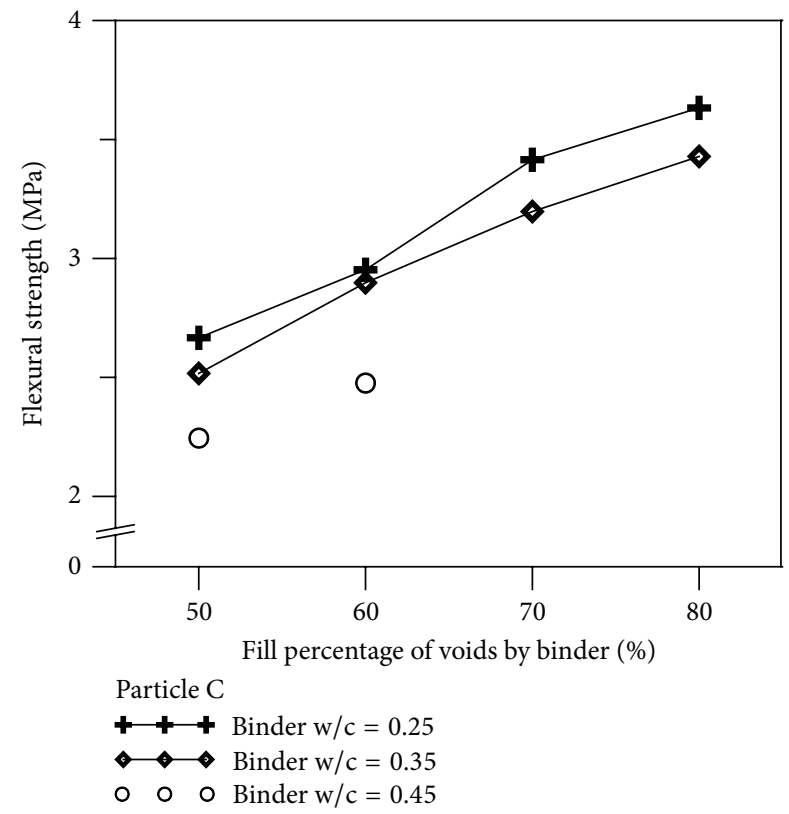

(c)

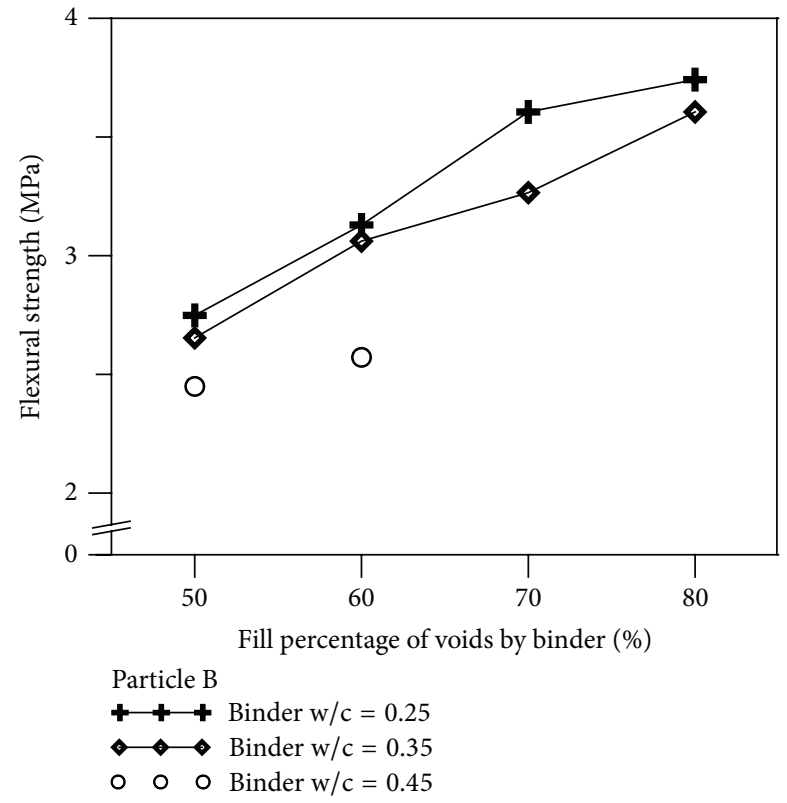

(b)

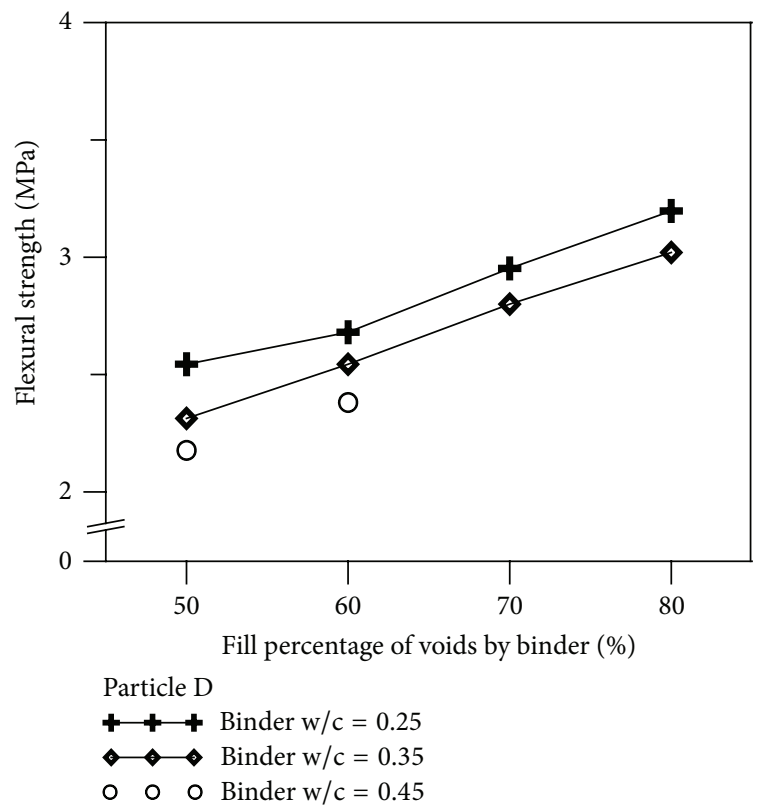

(d)

FIGURE 6: Flexural strengths of specimens comprising different particle sizes: (a) aggregate A; (b) aggregate B; (c) aggregate C; (d) aggregate D.

for water permeation. Specimens consisting of large particles had large sectional areas and straight paths. Thus, the velocity of the water infiltrated in the specimen differed, yielding variation in the flow volume of the water flowing out of the specimen.

(4) Mechanical strength decreased with increasing water permeability. Although using substantial amount of binders can enhance mechanical strength, permeability might decrease because the volume percent of binder-filled voids increases. The amount of binder used was directly proportional to mechanical strength, and increased aggregate size decreased mechanical strength.

(5) Alkali-activated slag paste with $\mathrm{L} / \mathrm{Sg}=0.35$ and 0.4 had greater mechanical strength than the cementpaste control did. Consequently, using appropriate amount of alkali-activated slag as a binder can effectively enhance the mechanical strength of pervious concrete. 


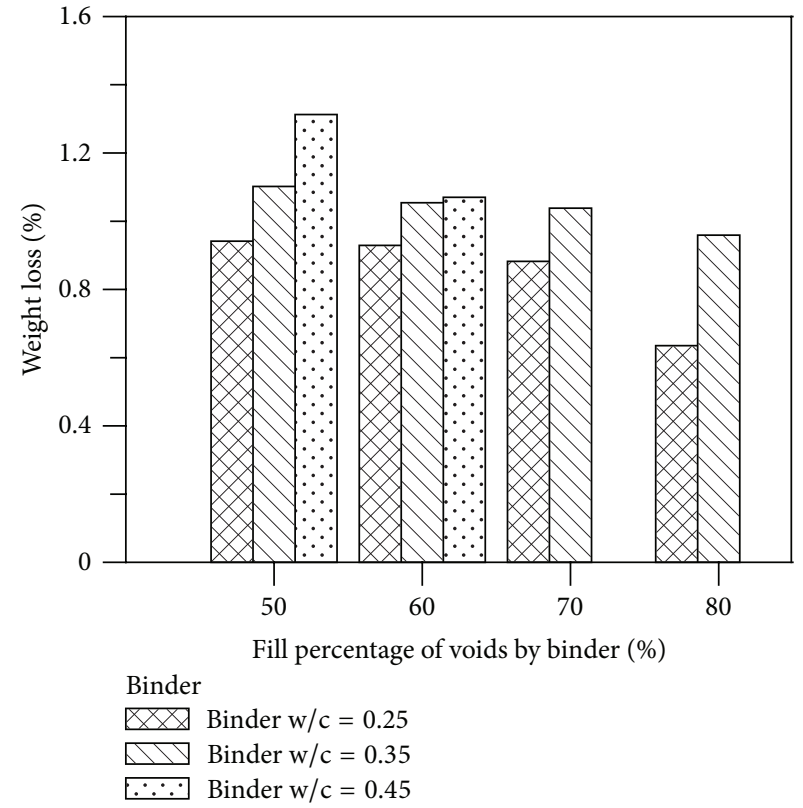

(a)

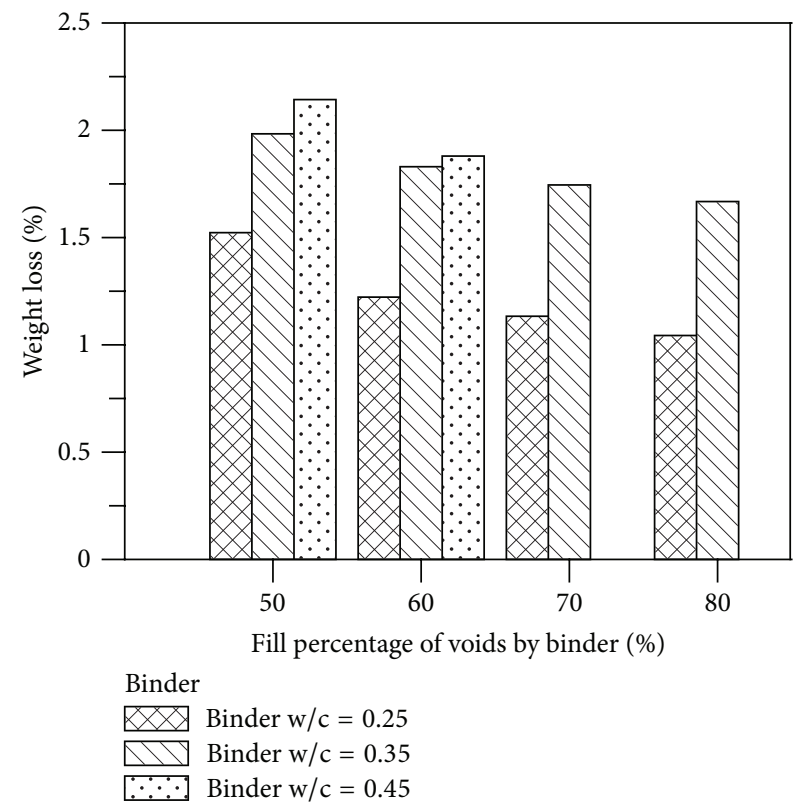

(c)

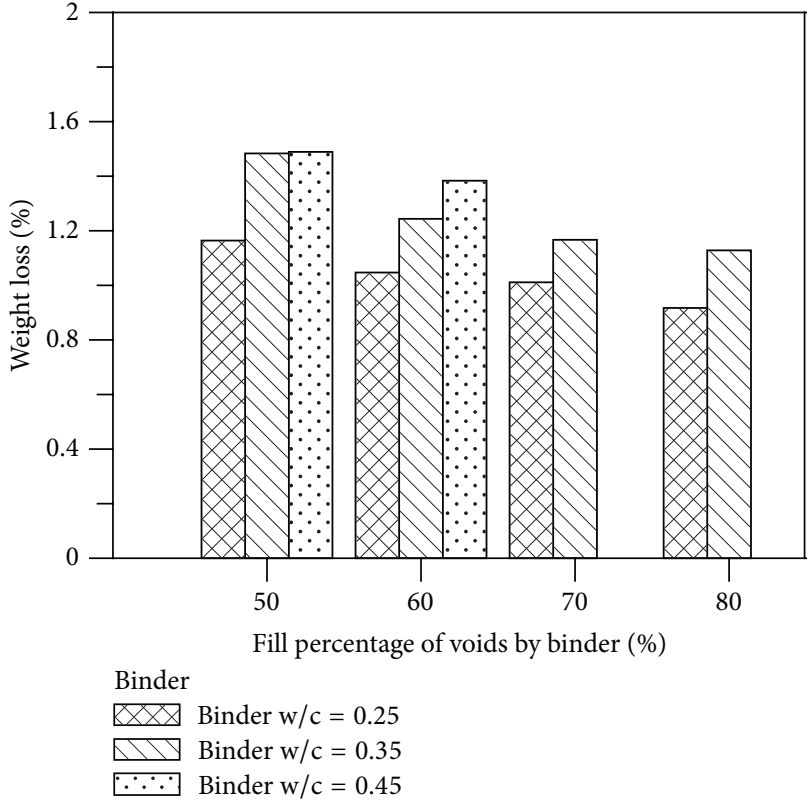

(b)

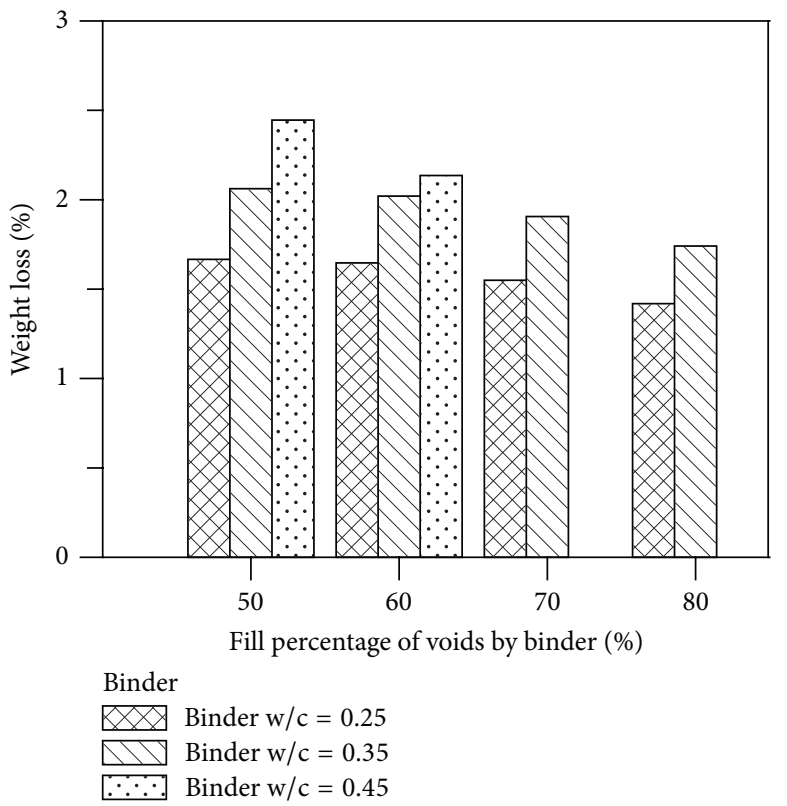

(d)

FIGURE 7: The weight loss percentages of specimens comprising different aggregate sizes that were immersed in a sulfate solution: (a) aggregate A; (b) aggregate $\mathrm{B}$; (c) aggregate $\mathrm{C}$; (d) aggregate $\mathrm{D}$.

(6) The mechanical strengths of the specimens with binders containing $10 \%$ silica fume were superior to those of the control specimen. This result was not observed for specimens with binders containing 20\% or $30 \%$ silica fume, possibly because excessive amount of silica fume was added. Therefore, adding a suitable amount of silica fume to binders can enhance the overall mechanical strength of pervious concrete.
(7) The weight-loss percentage of pervious concrete experiencing sulfate attacks increased as the $\mathrm{w} / \mathrm{c}$ ratio of cement pastes increased. Weight loss percentage was directly proportional to aggregate size, because the stacking of large aggregates generated large voids, which created paths for sulfate to infiltrate specimens and induce reactions. Specimens composed of alkaliactivated slag binder exhibited a superior resistance to 


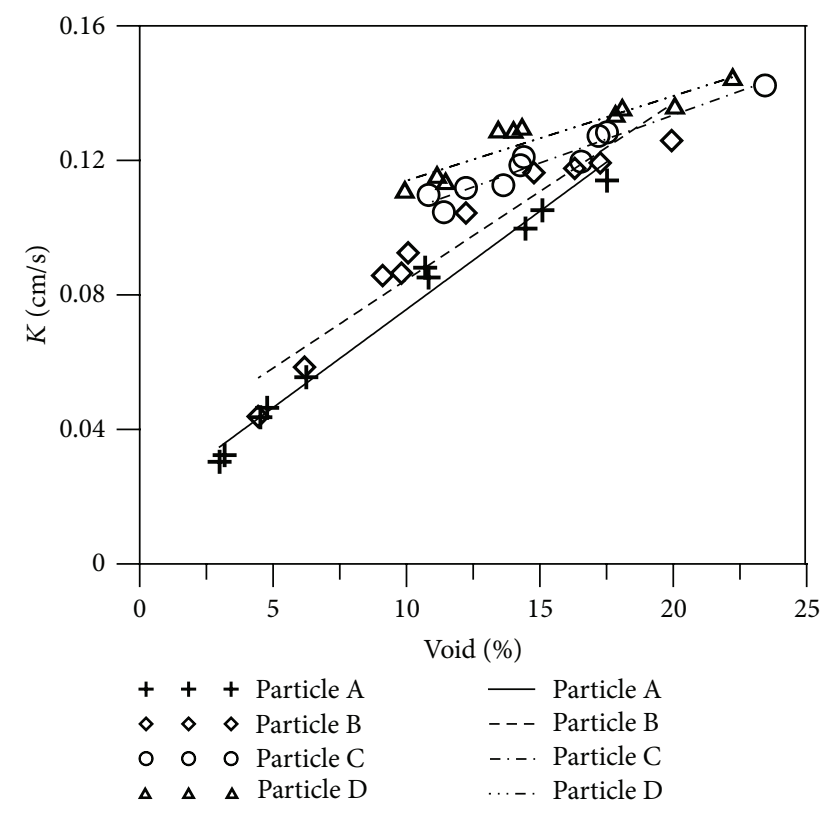

FIGURE 8: The relationship between porosity and water permeability coefficient.

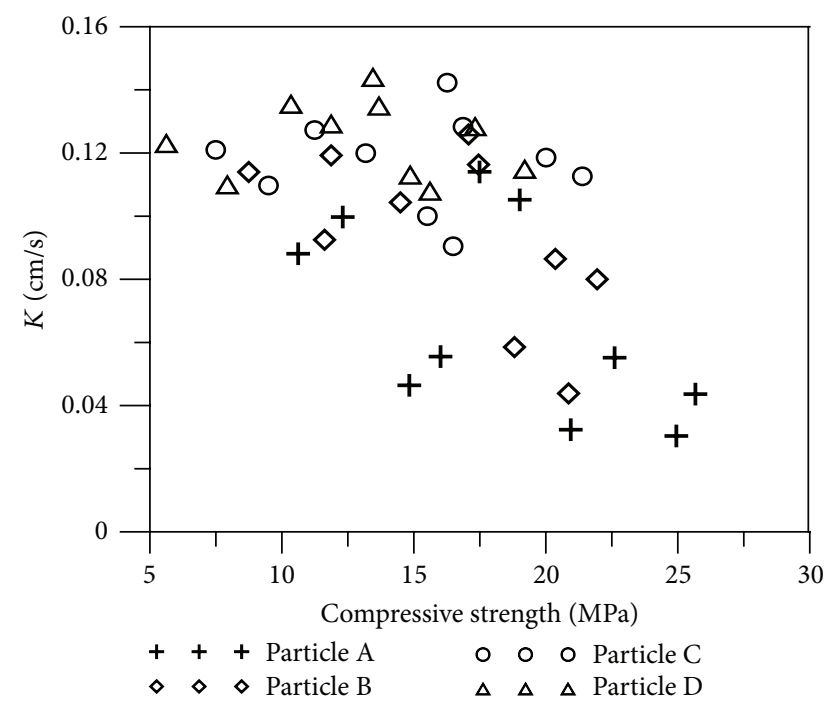

FIGURE 9: Correlation between compressive strength and water permeability coefficient.

sulfate attacks than those consisting of cement pastes did.

\section{Conflict of Interests}

The authors declare that there is no conflict of interests regarding the publication of this paper.

\section{References}

[1] J. Yang and G. Jiang, "Experimental study on properties of pervious concrete pavement materials," Cement and Concrete Research, vol. 33, no. 3, pp. 381-386, 2003.
[2] A. Marolf, N. Neithalath, E. Sell, K. Wegner, J. Weiss, and J. Olek, "Influence of aggregate size and gradation on acoustic absorption of enhanced porosity concrete," ACI Materials Journal, vol. 101, no. 1, pp. 82-91, 2004.

[3] S. B. Park, D. S. Seo, and J. Lee, "Studies on the sound absorption characteristics of porous concrete based on the content of recycled aggregate and target void ratio," Cement and Concrete Research, vol. 35, no. 9, pp. 1846-1854, 2005.

[4] S.-B. Park and M. Tia, "An experimental study on the waterpurification properties of porous concrete," Cement and Concrete Research, vol. 34, no. 2, pp. 177-184, 2004.

[5] B. Huang, H. Wu, X. Shu, and E. G. Burdette, "Laboratory evaluation of permeability and strength of polymer-modified pervious concrete," Construction and Building Materials, vol. 24, no. 5, pp. 818-823, 2010.

[6] L. K. Crouch, J. Pitt, and R. Hewitt, "Aggregate effects on pervious portland cement concrete static modulus of elasticity," Journal of Materials in Civil Engineering, vol. 19, no. 7, pp. 561$568,2007$.

[7] P. Chindaprasirt, S. Hatanaka, N. Mishima, Y. Yuasa, and T. Chareerat, "Effects of binder strength and aggregate size on the compressive strength and void ratio of porous concrete," International Journal of Minerals, Metallurgy and Materials, vol. 16, no. 6, pp. 714-719, 2009.

[8] P. Chindaprasirt, S. Hatanaka, T. Chareerat, N. Mishima, and Y. Yuasa, "Cement paste characteristics and porous concrete properties," Construction and Building Materials, vol. 22, no. 5, pp. 894-901, 2008.

[9] N. Neithalath, M. S. Sumanasooriya, and O. Deo, "Characterizing pore volume, sizes, and connectivity in pervious concretes for permeability prediction," Materials Characterization, vol. 61, no. 8, pp. 802-813, 2010.

[10] C. Lian, Y. Zhuge, and S. Beecham, "The relationship between porosity and strength for porous concrete," Construction and Building Materials, vol. 25, no. 11, pp. 4294-4298, 2011.

[11] D. R. Bentz, "Virtual pervious concrete: microstructure, percolation, and permeability," ACI Materials Journal, vol. 105, no. 3, pp. 297-301, 2008.

[12] B. J. Putman and A. I. Neptune, "Comparison of test specimen preparation techniques for pervious concrete pavements," Construction and Building Materials, vol. 25, no. 8, pp. 3480-3485, 2011.

[13] C. Lian and Y. Zhuge, "Optimum mix design of enhanced permeable concrete-an experimental investigation," Construction and Building Materials, vol. 24, no. 12, pp. 2664-2671, 2010.

[14] H. K. Kim and H. K. Lee, "Influence of cement flow and aggregate type on the mechanical and acoustic characteristics of porous concrete," Applied Acoustics, vol. 71, no. 7, pp. 607-615, 2010.

[15] H. Fujiwara, R. Tomita, T. Okamoto, A. Dozono, and A. Obatake, "Properties of high-strength porous concrete," ACI Structural Journal, vol. SP-179, pp. 173-188, 1998.

[16] M. Safiuddin and N. Hearn, "Comparison of ASTM saturation techniques for measuring the permeable porosity of concrete," Cement and Concrete Research, vol. 35, no. 5, pp. 1008-1013, 2005.

[17] L. M. Haselbach, S. Valavala, and F. Montes, "Permeability predictions for sand-clogged Portland cement pervious concrete pavement systems," Journal of Environmental Management, vol. 81, no. 1, pp. 42-49, 2006. 
[18] T. Tho-In, V. Sata, P. Chindaprasirt, and C. Jaturapitakkul, "Pervious high-calcium fly ash geopolymer concrete," Construction and Building Materials, vol. 30, pp. 366-371, 2012.

[19] J. J. Chang, W. Yeih, and C. C. Hung, "Effects of gypsum and phosphoric acid on the properties of sodium silicate-based alkali-activated slag pastes," Cement and Concrete Composites, vol. 27, no. 1, pp. 85-91, 2005. 

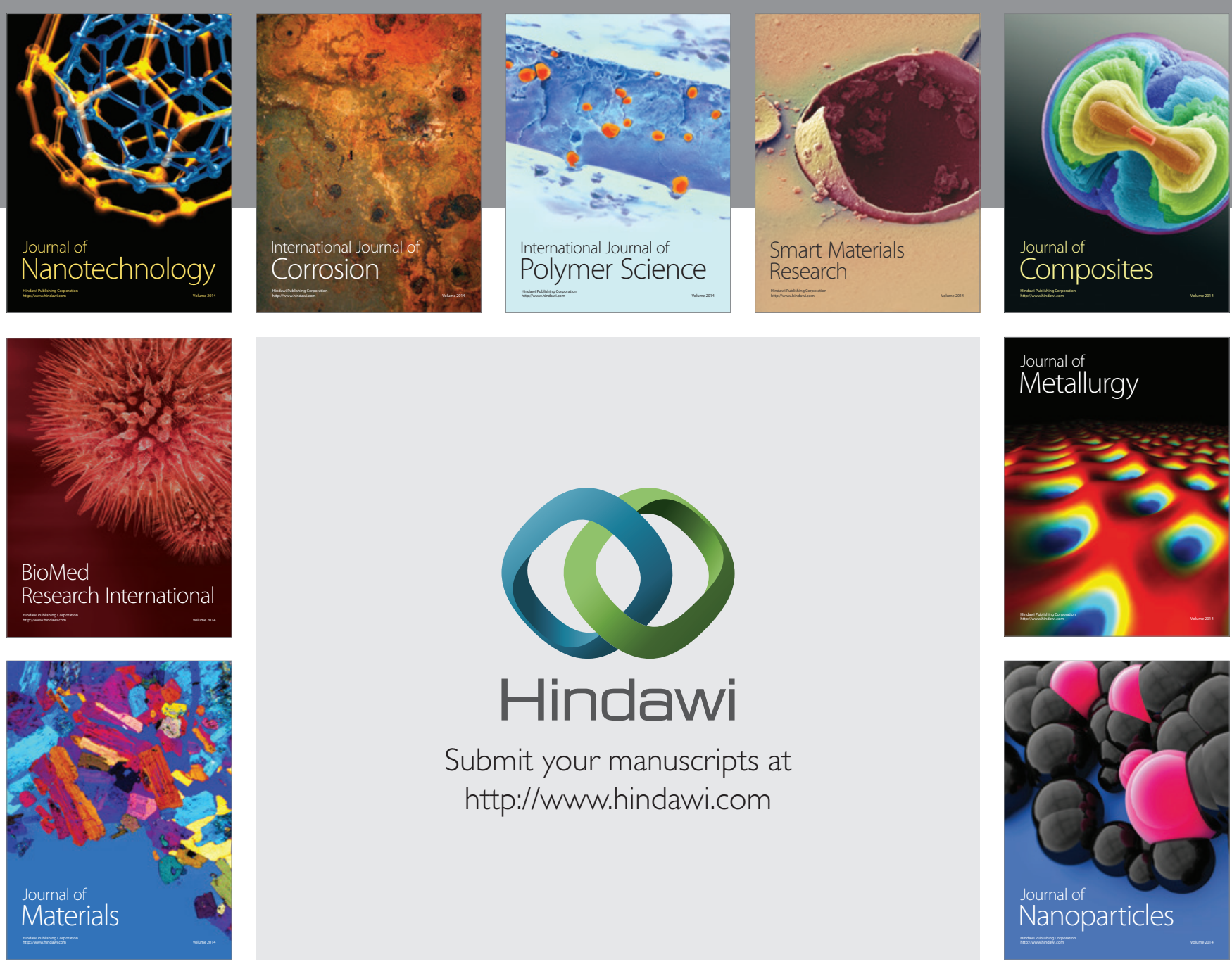

Submit your manuscripts at http://www.hindawi.com
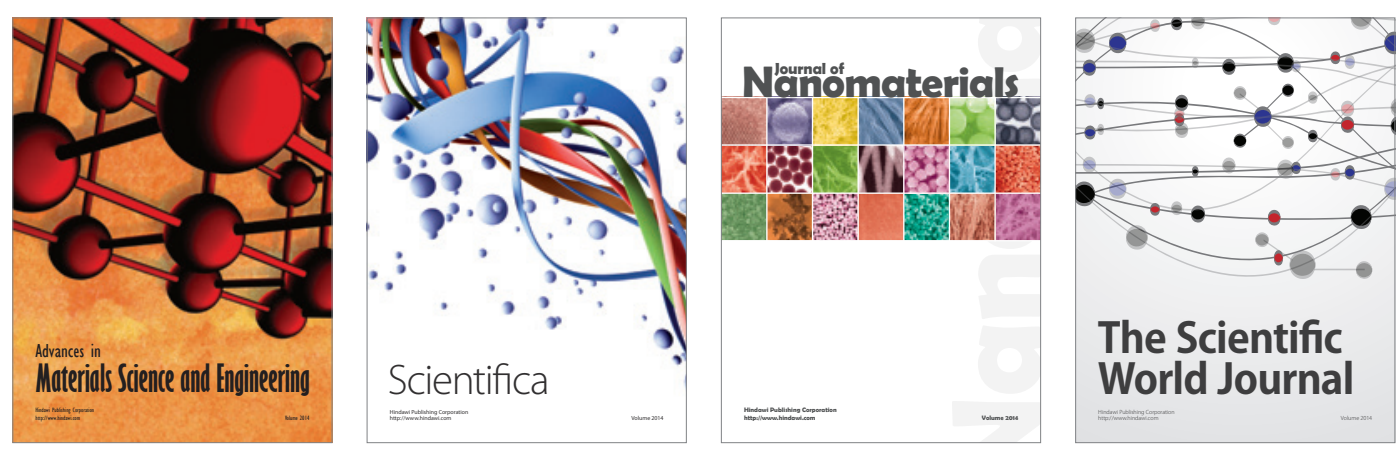

\section{The Scientific World Journal}
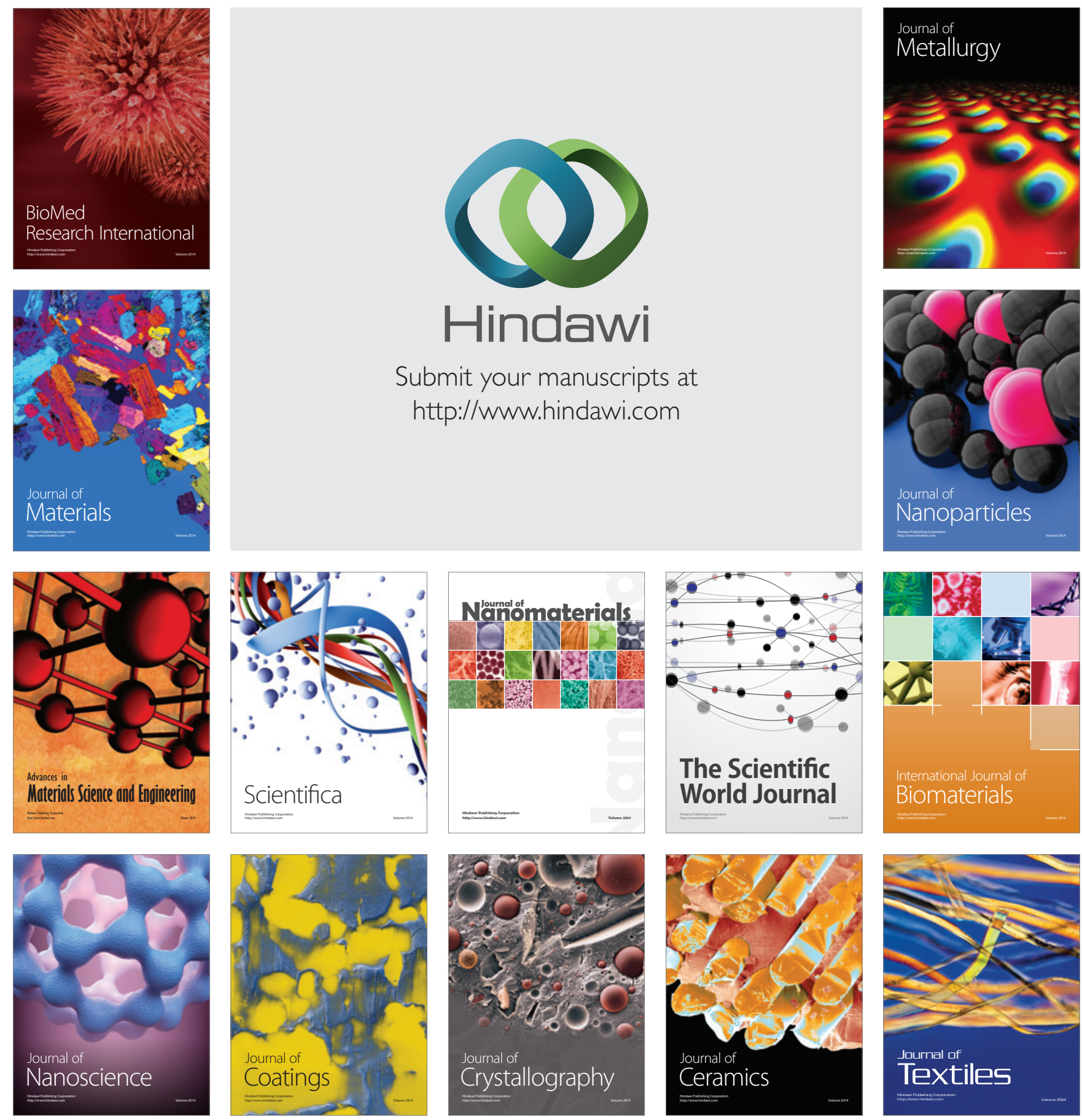